\title{
Why "Buy American" is a Bad Idea but Politicians still Like it
}

\author{
Mario Larch \\ Wolfgang Lechthaler
}

\author{
CESIFO WORKING PAPER NO. 3207 \\ CATEGORY 6: FisCAL POLICY, MACROECONOMICS AND GROWTH \\ OCTOBER 2010
}
An electronic version of the paper may be downloaded
- from the SSRN website:
- from the RePEc website:
- from the CESifo website:
www.SSRN.com
Www.RePEc.org
www.CESifo-group.org/wp




\title{
Why "Buy American" is a Bad Idea but Politicians still Like it
}

\begin{abstract}
When the world economy was recently hit by a severe recession, governments all over the world reacted by initiating stimulus packages. Some countries (among them, most notably, China and the US) tried to put special emphasis on their home industries by including "Buy local" clauses into the stimulus package. By analyzing the dynamics of transitory changes of trade barriers as a short-run response to an economic downturn, we show that beggar-thyneighbor policies do not work. We then come up with two rationales that help to understand why countries nevertheless consider protectionism to be a good response to a recession: (i) the lobbying of domestic, non-exporting firms, and (ii) the relationship between vulnerability, the degree of openness and loss aversion of consumers.
\end{abstract}

JEL-Code: F11, F12, F16.

Keywords: protectionism, trade liberalization, short term shocks.

Mario Larch

University of Bayreuth

Universitaetsstrasse 30

95447 Bayreuth

Germany

mario.larch@uni-bayreuth.de
Wolfgang Lechthaler

Kiel Institute for the World Economy

Duesternbrooker Weg 120

24105 Kiel

Germany

wolfgang.lechthaler@ifw-kiel.de

October 8, 2010 


\section{Introduction}

"But there is a short-run case for protectionism." (Paul Krugman, February 1, 2009, The New York Times)

During the great depression of the 1930s many countries tried to protect their economies by building up trade barriers. Today there is widespread agreement that these measures contributed importantly to the depth and persistence of the crisis. Nevertheless, there has been a worrisome, though still small, increase in protectionist measures as response to the latest global financial and economic crisis that started in 2008.

This is manifested in the latest figures about world trade development. In the course of the current crisis world trade has suffered tremendous decreases over the last few months. Over the first six months of 2009 world trade has seen an unprecedented slump of approximately $20 \%$ and was almost back to the level it had at the beginning of 2005. This phenomenon is not restricted to just a few countries, but has hit most economies around the globe.

As noted by Baldwin and Evenett (2009), so far this reduction is mainly due to the recession and not (yet) due to protectionist measures. Nevertheless, there has already been an increase in protectionist measures as documented, e.g., by IMF and World Bank (2009) or GlobalTradeAllert.org. Gamberonin and Newfarmer (2009) document that since the beginning of the crisis 17 of the G20 countries have implemented measures to restrict trade. According to Gregory, Henn, McDonald and Saito (2010) the protectionist measures that were implemented had a strong negative impact on trade.

At the beginning of 2009, the US-congress wanted to incorporate "Buy American" clauses in the huge stimulus package. After an outcry of policy-makers and economists around the globe, these measures have been cut down by a considerable degree. More recently China shocked the world community by announcing that it would use similar clauses for their stimulus package, ${ }^{1}$ while in September the Economist articulated in a leading article concerns about a new trade war following an announcement that the US wanted to raise tariffs on Chinese tyres. ${ }^{2}$ At the beginning of 2010 the world economy is showing signs of recovery. However, the fiscal stimuli of the crisis left the pockets of many governments empty and especially in this situation protectionism might be very tempting. As argued by Gregory, Henn, McDonald and Saito (2010), it is an opportunity to demonstrate activity that does not directly affect the government budget.

One may think that there is relatively little room for increasing protectionism due to the rules of the WTO. However, as argued for example in Bouet and

\footnotetext{
${ }^{1}$ See e.g. the report in the Wall Street Journal of June 18, 2009, available online at http://online.wsj.com/article/SB124520724753222171.html.

${ }^{2}$ See http://www.economist.com/printedition/displayStory.cfm?story_id=14450332.
} 
Laborde (2008), there is currently still much room for raising tariffs without violating WTO law. Most developed countries could increase tariffs by as much as $100 \%$, because they already set their tariffs lower than obliged. For low-income countries this margin is even higher.

Given the latest political debates about the "Buy American" clause and similar ambitions in China, one may ask if such policies really help countries to dampen the negative effects of economic crises and mitigate economic downturns.

Richard Baldwin and Simon Evenett (2009) brought together well-renowned researches to contribute to a recent VoxEU-E-book entitled "The Collapse of Global Trade, Murky Protectionism and the Crisis: Recommendations for the G20" in order to propose steps to counteract recent protectionist tendencies. Specifically, they suggest to: (i) Follow Keynes at home and Smith abroad: Fiscal stimulus packages are fine, but it should be taken care that the measures do not harm trade. Spill-overs to other countries are explicitly encouraged, or as Simon Crean put it: "nurture-thy-neighbor" instead of "beggar-thy-neighbor". (ii) Introduce a global surveillance mechanism: Assemble a team of independent experts to track protectionism and issue warnings in real-time. (iii) Agree on a temporary, legal-binding standstill on protection: Government leaders should commit on not to raise trade barriers for the duration of the global economic downturn. (iv) Do not abandon developing nations. (v) Facilitate trade as foundation for export-led recovery: Use the momentum of the crisis to accelerate the completion of the WTO's current negotiations on trade facilitation.

Especially the first point is criticized by Fredrik Erixon (2009). He argues that "higher government spending means more discretionary powers for politicians and bureaucrats, indiscriminate subsidies, rent-seeking and corruption" and "Big Government at home means a new age of protection abroad". Instead he calls for a "coalition of the willing" committing themselves to not raise tradebarriers. Kumar (2009) argues that the main problem lies in the shortage of credit and suggests the foundation of an "International Trade Financing Fund", a new international organization along the lines of IMF and World Bank with the mandate to finance trade of large global firms.

The E-book of Baldwin and Evenett (2009) also discusses some reasons why protectionism would hurt a country rather than protecting it from the global downturn: One argument is that through the global interlinkages and supply chains, import restrictions would harm domestic firms because input-costs are increased. Anne Krueger argues that import-competing goods would have higher prices and thus reduce demand, while Viktor Fung stresses the danger of retaliation from trading partners. In line with this, Hufbauer and Schott (2009) estimate that a "Buy American" clause could gain 10.000 jobs but lose as much as 65.000 through retaliation.

However, not all economists agree that protectionism is always bad. Most 
prominently, Krugman argued in one of his New York time columns ${ }^{3}$ that there is a short-run case for protectionism. His argument is that due to international spillovers the size of stimulus packages is too small. Employing "Buy Local" clauses reduces these externalities.

It is the purpose of this paper to thoroughly analyze the effects of protectionism as a short-run response to an economic downturn. In order to capture the short-run effects properly, it is necessary to look at the dynamics out of steady-state. However, most of the literature in international trade focusses on the steady-state effects of trade liberalization. And even though there are some papers dealing with dynamics, none of them has a focus similar to ours. We will briefly summarize these papers here. ${ }^{4}$

Costantini and Melitz (2007) develop a dynamic model of firm-level adjustment to trade liberalization that captures the self-selection of more productive firms into export markets, the joint export market participation and innovation decisions, and the continuing innovation of other firms following their entry into export markets. They compare three scenarios: (i) an unanticipated, abrupt decrease in trade costs; (ii) an abrupt change in trade costs, anticipated three years in advance; (iii) and an anticipated but gradual change in trade costs. One of their main findings is that the anticipation of future liberalization induces many new exporters to innovate already before the actual liberalization, and also before their own entry into the export market.

Ghironi and Melitz (2005) provide in a dynamic general equilibrium model with trade in bonds the effects of a symmetric lowering of variable and fixed trade costs. In both scenarios, trade liberalization induces a substantial increase in the number of exporting firms, along with a decrease in the export productivity cutoff (exporting becomes more profitable for all firms), as in the standard Melitz (2003) framework. In line with many micro-level studies of trade liberalization, a substantial portion of the increase in overall trade comes from the extensive margin (more exporting firms). Brůha and Podpiera (2007) extend the Ghironi and Melitz (2005) framework by endogenizing the vertical investments (investments into quality improvements) in order to replicate the observed pace of the real exchange rate appreciation in Central and Eastern European countries. Concerning trade liberalization, they investigate an exogenous, permanent fall in trade costs at a specific point in time. They find that the smaller country borrows to finance entry of additional firms, i.e., relatively more firms enter in the smaller country because of the export market effect, leading to an increase in GDP and an appreciation of the exchange rate.

Albuquerque and Rebelo (2000) consider reforms with different degrees of permanence and timing and find that even though it is optimal to immediately

\footnotetext{
${ }^{3}$ Available at http://krugman.blogs.nytimes.com/2009/02/01/protectionism-and-stimuluswonkish/.

${ }^{4}$ We do not survey the trade and growth literature, which also investigates adjustment dynamics. See for a good monograph Grossman and Helpman (1991).
} 
liberalize international trade, these reforms may not take place because of concern over their impact on the distribution of income. A similar result is obtained by Bacchetta and Dellas (1997), who show that the case for gradualism becomes stronger when there is more emphasis on the longer term allocation of resources. Antras and Caballero (2010) study in a dynamic general equilibrium model based on Antras and Caballero (2009) with financial frictions how trade liberalization effects income, consumption and the distribution of wealth in financially underdeveloped economies.

Another part of the literature focuses on reasons for gradual trade reforms. Mussa (1986) and Leamer (1980) show that unilateral trade liberalization in the presence of adjustment costs, i.e. costs for workers to move from one industry to another, may make gradualism preferable especially to reduce the pain of workers in the protected sector. Staiger (1995) attributes gradualism in trade liberalization to self-enforceability of agreements. Furusawa and Lai (1999) show that self-enforceability of bilateral trade liberalization together with adjustment costs for workers are also sufficient to induce gradualism.

In contrast to all of the above papers which are mainly concerned with the transition from one steady-state to another, we extend the current literature by explicitly focusing on the dynamics of transitory changes of trade barriers as a response to economic shocks. In order to capture the relevant transmission mechanisms of changes in trade costs, such as market size and productivity changes of firms, ${ }^{5}$ we build on the work by Melitz (2003) and specifically rely heavily on the dynamic version introduced by Ghironi and Melitz (2005). While the basic Melitz (2003) framework only allows for comparisons of different steady-states, the Ghironi and Melitz (2005) framework is well suited for the analysis of the current crisis since it allows for deviations from the long-run equilibrium, in other words, it allows for recessions. Most of the macro models that analyze transitional dynamics either assume closed economies or trade based on the assumption of "Armington" (1969) preferences. The latter does not allow to distinguish firm dynamics based on adjustments at the extensive margin, i.e., the set of firms, and the intensive margin, i.e., the size of firms. However, recent empirical work reveals that the often ignored extensive margin is an important adjustment margin and that the intensive and extensive margins' sensitivity to policy interventions such as trade liberalization is different. ${ }^{6}$ In line with these recent findings, we allow

\footnotetext{
${ }^{5}$ Its popularity stems from the combination of being able to capture important stylized facts, like the fact that only very productive firms export, that exporters are bigger and employ more workers than domestic firms, and that small firms with low productivity are driven out of the market, while it remains still very tractable. See the empirical studies by Dunne, Roberts and Samuelson (1989); Davis and Haltiwanger (1992); Bernard and Jensen (1995, 1999, 2004); Roberts and Tybout (1997); Clerides, Lach and Tybout (1998); and Bartelsman and Doms (2000) for evidence concerning the stylized facts.

${ }^{6}$ See for example Chaney (2008), Helpman, Melitz and Rubinstein (2008), and Bernard, Jensen, Redding and Schott (2007, 2009).
} 
for exit and entry of firms and find that both, adjustments at the extensive and intensive margin, are important ingredients of our analysis, leading protectionism to redistribute resources to less efficient firms.

It is quite obvious that we are currently not in a long-run equilibrium and thus a sensible analysis of protectionism in the current crisis needs to take this into account. We therefore explicitly study transitional dynamics. Here we depart from the traditional international trade literature, which focuses on the gains from trade liberalization by comparing steady-state outcomes (see for example Feenstra (2004) for a discussion of the "gains from trade" hypothesis). Specifically, we are interested in whether it is a good idea to respond with protectionism in the case of a negative demand shock. We investigate various scenarios, where we distinguish whether the trading partner responds to increased trade barriers or not. The main conclusion is that protectionism hurts all countries, including the country imposing the protectionist measures, even if the other countries do not react with protectionism by themselves. Thus, the results from our model yield a powerful argument against protectionism.

Nevertheless, many policy makers seem to like protectionist measures. Is there a way to rationalize this? The answer is yes. There are two rationales that help to understand why countries consider protectionism to be a good idea as a response to a recession: (i) Firms are hit differently by protectionism. Actually, domestic firms that do not export at all gain in terms of total profits from raising trade barriers. Hence, whenever domestic firms that do not export have a strong lobby, a government may raise trade barriers in order to gain political support for the next election. (ii) Openness increases the vulnerability of a country with respect to shocks occurring in a trading partner country. As loss-avers individuals are likely to favor protectionism in the wake of a crisis, they may put pressure on politicians to increase trade barriers.

\section{The Model}

In this section we describe the model framework underlying our analysis. As we follow closely the Ghironi and Melitz (2005) model, allowing for international capital flows, we describe only the key features that are important to understand our results. The inclined reader is referred to the Technical Appendix and to the article of Ghironi and Melitz (2005).

Households. The model features two countries with monopolistic competition and flexible prices. Households supply labor inelastically and maximize expected intertemporal utility from consumption. At any given time, the consumption basket, $C$, is defined as a CES aggregate over a continuum of varieties. For simplicity, we assume that domestic and foreign varieties enter symmetrically in the consumption index. ${ }^{7}$ In order to study the effects of demand shocks, we

\footnotetext{
${ }^{7}$ Allowing for a lower elasticities of substitution between foreign and domestic varieties as
} 
follow the macroeconomic literature and introduce an exogenous component to consumption $\bar{C}$, ${ }^{8}$ which consists of the same varieties as $C$.

Firms. There is a continuum of firms in each country, each producing a different variety. There is only one factor of production, labor. Firms are heterogeneous due to differences in technologies, reflected in differences in labor productivity. Before entering the market, firms are identical and have to incur a sunk entry cost in the form of labor requirements. Upon entry, firms draw their relative productivity level, which is assumed to stay constant thereafter, from a known distribution. In contrast to Melitz (2003), there are no other fixed production costs, implying that all firms produce until they are hit by a death shock, which occurs with an exogenous probability $\delta$.

Exporting. Besides serving the domestic market, a firm may export. However, exporting involves both a per-unit "iceberg" cost as well as a period-byperiod fixed cost measured in labor units. Exporting fixed costs lead to a sorting of the most productive firms into exporting. Hence, firms with relatively low productivity levels choose to only serve their domestic market. The varieties from firms serving only the domestic market are thus not available abroad. We assume an unbounded mass of forward-looking potential entrants that correctly anticipate their future expected profit $\tilde{d}_{t}$ in every period. Entrants at time $t$ only start producing at time $t+1$, which introduces a one-period time-to-build lag in the model. The exogenous exit shock occurs at the very end of the time period (after production and entry). A proportion $\delta$ of new entrants will therefore never produce. Home entrants in period $t$ compute their expected post-entry value given by the present discounted value of their expected stream of profits $\left\{\tilde{d}_{s}\right\}_{s=t+1}^{\infty}$ :

$$
\tilde{v}_{t}=E_{t} \sum_{s=t+1}^{\infty}[\beta(1-\delta)]^{s-t} \frac{C_{s}^{-\gamma}}{C_{t}^{-\gamma}} \tilde{d}_{s},
$$

where $C_{s}^{-\gamma}$ is marginal utility of consumption at time $s, \beta \in(0,1)$ is the subjective discount factor of households and $\gamma>0$ is the inverse of the intertemporal elasticity of substitution. Firms discount future profits using the household's stochastic discount factor, adjusted for the probability of firm survival $1-\delta$. Entry then occurs until the expected present discounted value of future profits $\tilde{v}_{t}$ is equalized with the sunk entry costs. It is assumed that macroeconomic shocks are small enough so that there is positive entry in every period and the above condition holds. Note that as the profitability of the export market changes over time, also the set of traded and non-traded goods fluctuates over time.

International Capital Flows. Households in each country hold two types of assets: shares in a mutual fund of domestic firms and domestic and foreign

compared to the elasticity of substitution between all domestic varieties and between all foreign varieties, would lead to a "home bias": Consumers would prefer domestic varieties over foreign ones. This would lead to a lower volumes of trade. Hence, it has qualitatively similar effects as higher levels of trade barriers in the initial situation.

${ }^{8}$ See e.g. Lewis (2009) for an application in a setting with endogenous firm entry. 
bonds. Since the household does not know which firms will be hit by the exogenous exit shock $\delta$, the mutual fund fully diversifies the idiosyncratic risk of firm death. Hence, investment in share holdings finances the creation of new firms. Due to the allowance of international capital flows via bonds trading, households may transfer resources across countries to smooth consumption and generate additional resources for firm creation. International borrowing and lending results in current account fluctuations. The trade balance is obtained as the difference between aggregate exports and imports in each period. The trade balance embodies the contributions to trade of both the extensive margin (the number of firms that export in each country) and the intensive margin (exported output per firm).

Calibration. We assume that the productivity of firms is distributed Pareto, which fits firm-level data quite well. Periods represent quarters. The subjective discount rate $\beta$ is set equal to 0.99 , implying a steady-state interest rate of approximately four percent. The inverse of the intertemporal elasticity of substitution $\gamma$ is set equal to 2 , which is a standard choice for business cycle models. The exogenous death shock is set equal to 0.025, which matches the U.S. empirical level of 10 percent job destruction per year. Relying on Obstfeld and Rogoff (2001) we set the steady-state value of trade $\operatorname{costs} \tau$ equal to 1.3. The steadystate fixed export cost $f_{X}$ is set to 23.5 percent of the per-period, amortized flow value of the entry cost, $[1-\beta(1-\delta)] /[\beta(1-\delta)] f_{E}$, such that the proportion of exporting plants matches the 21 percent reported in Bernard, Eaton, Jensen, and Kortum (2003). Entry costs $f_{E}$ are set to 1 without loss of generality, as changing $f_{E}$ while maintaining the ratio $f_{X} / f_{E}$ does not affect any of the impulse responses. For similar reasons, we normalize labor endowments to 1, i.e., $L=1$ and $L^{*}=1$. In steady-state, the exogenous part of consumption is $10 \%$ of endogenous consumption.

Parametrization of Shocks. In the following, we consider a negative shock to the exogenous component of aggregate demand in one country in the order of $10 \%$ of the steady-state value. In line with Ghironi and Melitz (2003) (and the business-cycle literature) we assume that the shock has long-lasting but not permanent effects so that aggregate demand slowly converges back to its steadystate value according to

$$
\bar{C}_{t}=\bar{C}^{1-\rho} \bar{C}_{t-1}^{\rho} e^{-u_{t}},
$$

where $\bar{C}$ (without time index) is the steady-state value of exogenous consumption, $u_{t}$ is the shock term and $\rho$ is the autocorrelation parameter, set equal to 0.9 if nothing else is mentioned.

If a country wants to react to this shock by using trade policy, we assume that it will do so by following a similar pattern: It increases trade-costs by $1 \%$ and then slowly reduces them back to its old steady-state value (with the same parameter of autocorrelation):

$$
\tau_{t}=\tau^{1-\rho} \tau_{t-1}^{\rho} e^{-u_{t}}
$$


This pattern is equivalent to the way in which fiscal or monetary policy reactions are modeled in the business-cycle literature. ${ }^{9}$

\section{Protectionism and the Business Cycle}

In this section we analyze the consequences of protectionism in response to a temporary negative shock to the exogenous demand of country 1, called "America" in the subsequent. To do so we distinguish between three different scenarios. i) First, we analyze the case when America, where the shock occurs, raises trade barriers ("Buy American"). The reason for raising trade barriers may be seen in trying to shift demand from imported goods to home products, thereby trying to mitigate the demand shock. ii) Second, we analyze the case when the trading parter, called in the subsequent "Canada", is raising trade barriers to protect itself from the recession in America ("Buy Canadian"). iii) Finally, we illustrate the consequences of retaliation. We will show that in each case, protectionism is a bad idea, not only hurting the trading partner but also the country that raises the trade barriers.

\subsection{Buy American}

Before we start with the discussion of trade policy let us first describe the effects of the drop in demand and its consequences for both countries. For an illustration see the solid line in Figure 1. For America, on impact overall (exogenous plus endogenous) consumption and output go down. ${ }^{10}$ The decrease in exogenous consumption is met by an increase in endogenous consumption but this can only partially offset the downturn. Furthermore, the decrease in demand directly decreases imports ${ }^{11}$ and therefore the trade balance becomes positive.

Note that the change in output and consumption turns positive after 14 periods. This is due to the desire of households to smooth consumption implying that the (positive) change in endogenous consumption takes longer to get back to its steady-state value than the (negative) change in exogenous consumption. ${ }^{12}$

In Canada the decrease in foreign demand also implies a decrease in output. However, some of the resources formerly used for exports now go into domestic production and therefore private consumption goes up. ${ }^{13}$

\footnotetext{
${ }^{9}$ See e.g. Galí (2008) or Galí, López-Salido and Vallés (2007).

${ }^{10}$ In this graph and all futures graphs consumption is the sum of exogenous and endogenous consumption.

${ }^{11}$ Note that the exogenous part of demand also shows up in the demand for foreign products.

${ }^{12}$ This is a standard result in the literature. See e.g. Uhlig (2010).

${ }^{13}$ This was of course not the case in the current crisis. A simultaneous decrease in consumption in both countries could be achieved by using correlated shocks to the exogenous part of consumption in both countries or by adding productivity shocks. However, for the analysis of protectionism this is irrelevant and therefore we stick to the simple shock-processes, making it
} 

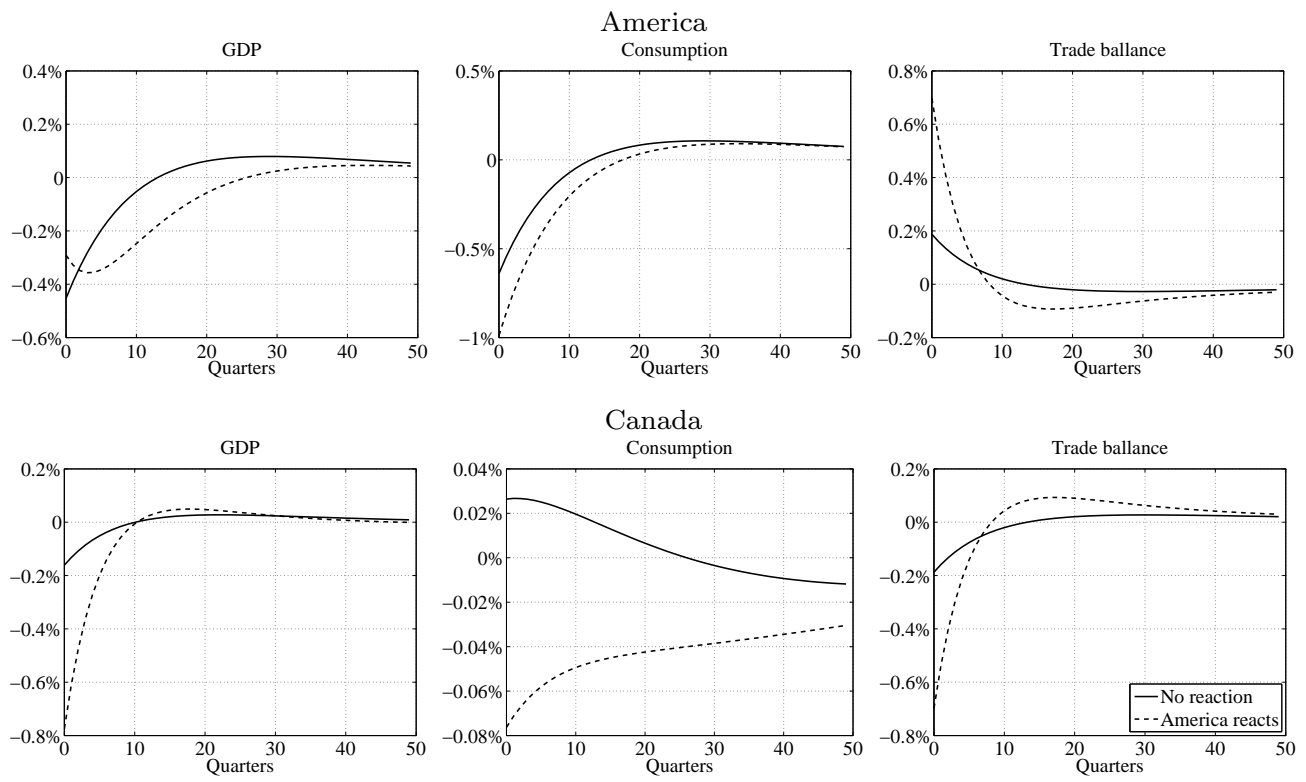

Figure 1: Buy American: America raises trade barriers.

Having described the situation without changes in trade policy let us now assume that America tries to counteract and dampen the decrease in demand by shifting demand from foreign goods to domestic goods. In other words, America, where the shock occurs, raises trade barriers. We model this by assuming that the trade costs for goods sold from Canada to America are increased, while the trade costs in the opposite direction stay the same. It is assumed that the increase in trade costs does not yield any direct returns to the government. In other words the increase in trade costs is not due to an increase in tariffs but rather due to non-tariff barriers. This is very much in line with the empirical facts of the current crisis, as documented by Baldwin and Evenett (2009).

Figure 1 compares the Buy American scenario with the case where trade policy does not change. The effects for Canada in the lower panel are not very surprising. The increase in trade barriers further reduces exports and output. Consumption which was actually increasing without the increase in trade barriers is now dropping, too, and recovering only very slowly. ${ }^{14}$ Notable is the size of the impact. The drop in GDP is now about four times larger, than it was without protectionism.

What is maybe more surprising is the fact that this does not help America.

easier to interpret results. See e.g. Backus, Kehoe and Kydland (1992) for a discussion about business-cycle comovements.

${ }^{14}$ Looking at the graph it even appears that consumption in Canada is permanently lower. This is not the case, but consumption takes a very long time to get back to its steady-state value. 
In sharp contrast, for America things get much worse, too. The decrease in consumption on impact is almost doubled. Looking at output there is only a small positive effect on impact, rapidly turning negative. The recession is much longer and deeper in America when it raises trade barriers. This is true even if Canada is not reacting with retaliation.

The result is partially explained by the effects of trade barriers on the real exchange rate (not depicted). The increase in trade barriers results in a sharp increase of the price level in America relative to Canada. As a result exports drop by more than 4 percent. At the same time imports drop by even more (due to the increase in trade barriers). These changes have two important implications. Less business opportunities for exporting firms and higher prices for consumers (imports become more expensive). Basically, this kind of trade policy is redistributing production from highly productive exporting firms to domestic firms with relatively low productivity. As motivated in the introduction, this shift at the extensive margin was found to be important empirically. Only by employing a dynamic heterogeneous firm model we are able to capture changes at the extensive margin and the heterogeneous responses of firms to trade liberalization.

\subsection{Buy Canadian}

Next we take the perspective of the trading partner. Assume that Canada tries to shield itself from the economic downturn in America and therefore raises import restrictions in order to protect import competing firms from cheap exports. In contrast to above, in this scenario we assume that America does not change its trade policy. The results are illustrated in Figure 2.

Again both countries are hurt by this kind of trade policy. Although Canada succeeds in overturning the trade deficit into a trade surplus, this comes at a high cost. Canada suffers a large decrease in consumption and the recession becomes deeper and much more persistent. In fact, the boom that typically follows such a recession never occurs. The reasons are the same as in the experiment above. The country initiating the protectionism is hurt by changes in relative prices, the trading partner by the increase in trade barriers. Exports and imports go down in both countries and thus high-productivity firms produce less while lowproductivity firms produce more.

So far we have assumed that one country does not care about the increase in trade barriers of the other country. However, it is much more likely that a country that is hurt by protectionism will resort to protectionist measures on its own. This scenario is described in the next section.

\subsection{Retaliation}

During the great depression the attempts of some countries to shield themselves by erecting trade barriers were retaliated by other countries which in turn raised 

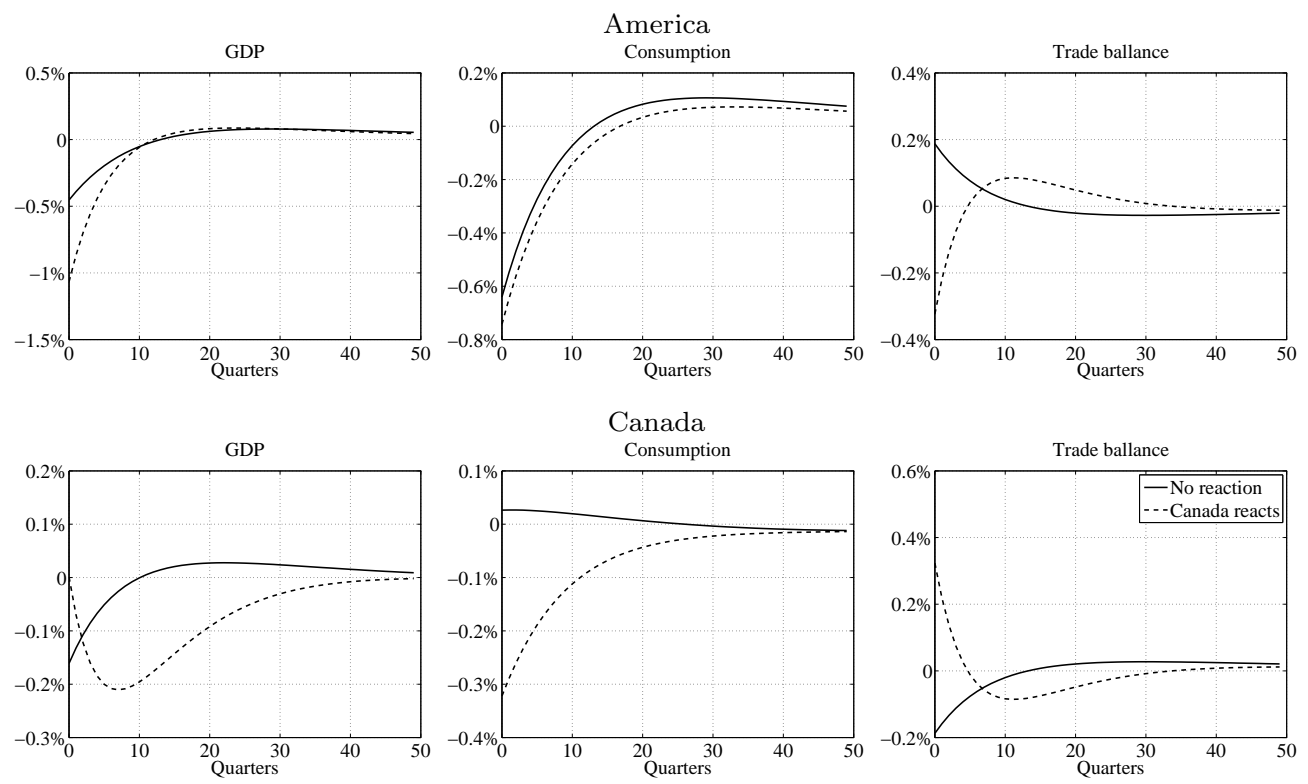

Figure 2: Buy Canadian: Canada raises trade barriers.

trade barriers and thereby started a vicious cycle that proofed to be disastrous. Therefore we analyze in this subsection a third scenario in which both countries increase trade barriers. For simplicity we assume that both countries react immediately to the drop in demand and that both countries increase trade barriers by the same amount. ${ }^{15}$ The resulting effects are illustrated in Figure 3, showing scenario one and three in one graph. In line with the results of the previous sections, retaliation only makes matters worth for both parties.

The real exchange rate is brought back exactly to the path it had without any changes in trade costs and the same is true for the trade balance (hence, the lines for the trade balance in Figure 3 of "No reaction" and "Both countries react" overlap). In this respect, the two policy reactions seem to offset each other. However, hidden behind this zero net effect on the trade balance is a huge decrease in exports in both countries (more than 10 percent). The retaliation of Canada deepens the inefficient redistribution of output between relatively unproductive domestic firms and highly productive exporting firms, in this way further wasting resources. This results in a stronger decline in output and consumption in both countries. Thus, the raising of trade barriers again not only hurts the trading partner but also the country imposing them.

\footnotetext{
${ }^{15}$ One might argue that it is not very realistic to assume that Canada reacts immediately to the protectionist measures in America. However, our results are not sensitive to the assumption about the timing of events. Assuming that Canada reacts one or more periods later would only delay but not change the effects of protectionism.
} 

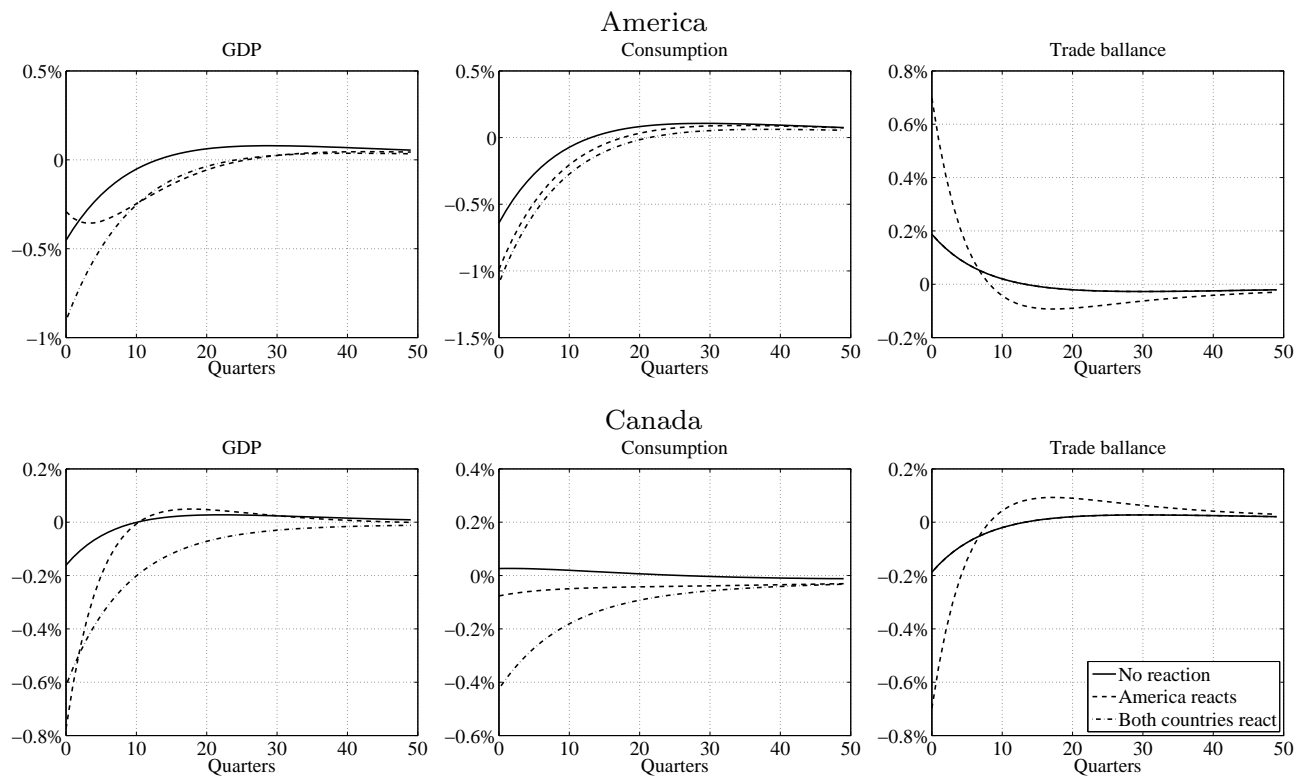

Figure 3: Retaliation: both countries raise trade barriers.

\subsection{Changes at the Intensive and Extensive Margin}

As motivated in the introduction, key for the analysis of short-term trade policy responses to demand shocks is the distinction between effects on the intensive margin (the size of firms) and the extensive margin (the number of firms). In Table 1 we therefore decompose the change in GDP into changes on the extensive and intensive margin. The table also summarizes the results of the previous sections.

Each number in the table reports the change in the discounted present value (from period one up to the number indicated in the column headline) of the respective variable caused by protectionism in the three different scenarios (i.e. the difference between the recession without protectionism and the recession with protectionism). So, e.g., the second column shows the effect in the first period while the fourth column shows the sum of the discounted effects in periods 1 to 8. For GDP and consumption the numbers are reported as percent of their respective steady-state values. For the extensive and the intensive margin the numbers are reported as percent of steady-state GDP.

The basic pattern is the same in all three scenarios. Protectionism (no matter whether it is done by America, Canada or both) leads to decreases in output along the extensive margin and to increases along the intensive margin. This means that protectionism increases the output per firm but reduces the number of firms.

Higher trade barriers have two effects. On the one hand they change relative prices, making domestic varieties relatively more attractive compared to foreign varieties. On the other hand they shield domestic firms from foreign competi- 
tion, leading to higher prices, higher wages, and higher market entry costs. The reduction on the extensive margin is mainly driven by the decrease of exporting firms, which stems from the former effect of the change in relative prices. The increase of output stemming from the intensive margin is due to the latter effect, leading to higher residual demand of American firms due to lower competition from Canada's exporting firms.

Table 1: Short- and long-term responses for America

\begin{tabular}{lrrcrr}
\hline \hline Periods & \multicolumn{1}{c}{1} & \multicolumn{1}{c}{8} & \multicolumn{1}{c}{16} & \multicolumn{1}{c}{100} \\
\hline Buy American (Figure 1): & & & & & \\
$\Delta$ Consumption & -0.349 & -1.195 & -1.973 & -2.808 & -3.381 \\
$\Delta$ GDP & 0.162 & 0.136 & -0.452 & -1.769 & -3.365 \\
$\Delta$ Extensive margin & -0.509 & -2.181 & -4.301 & -7.286 & -10.176 \\
$\Delta$ Intensive margin & 0.671 & 2.317 & 3.849 & 5.516 & 6.811 \\
\hline Buy Canadian (Figure 2): & & & & & \\
$\Delta$ Consumption & -0.103 & -0.379 & -0.689 & -1.158 & -2.257 \\
$\Delta$ GDP & -0.613 & -1.710 & -2.209 & -2.197 & -2.267 \\
$\Delta$ Extensive margin & -0.867 & -2.552 & -3.559 & -4.076 & -4.726 \\
$\Delta$ Intensive margin & 0.254 & 0.842 & 1.350 & 1.879 & 2.459 \\
\hline Retaliation (Figure 3): & & & & & \\
$\Delta$ Consumption & -0.451 & -1.572 & -2.654 & -3.955 & -5.625 \\
$\Delta$ GDP & -0.451 & -1.572 & -2.654 & -3.955 & -5.625 \\
$\Delta$ Extensive margin & -1.375 & -4.727 & -7.839 & -11.330 & -14.875 \\
$\Delta$ Intensive margin & 0.924 & 3.154 & 5.185 & 7.375 & 9.250 \\
\hline \hline
\end{tabular}

Numbers indicate changes in present discounted values up to the respective period given in the column headline.

\section{Two Rationales for Protectionism}

So fare we have seen that both countries are worse off in terms of consumption if they react with increases in trade barriers after a negative demand shock. However, as discussed in the introduction, the voices for protectionism during the great depression were loud and came up again with the latest downturn of the economy. Hence, one might wonder if it is possible to make a case for protectionism. In other words, is there any chance in our framework to rationalize why countries consider protectionism as a good idea at all? The answer is yes.

In fact, one can come up with at least two rationales that help to understand why protectionism may be seen as a good idea as a response to a recession: (i) the lobbying of domestic, non-exporting firms, (ii) the relationship between vulnerability and the degree of openness to trading partner countries. We discuss each in turn. 


\subsection{The Effects on Domestic, Non-Exporting Firms}

Firms are hit differently by protectionism. In Figure 4 we show total profits for two types of firms: a) a firm with low productivity, only serving the domestic market, and b) a firm with high productivity, also serving the foreign market. The upper panel shows total profits for both types of firms, while the lower panel sub-divides total profits of the high productivity firm into profits from the domestic market and profits from the export market.

Let us focus first on the results for America. As can be seen, profits of purely domestic firms in America increase when America raises trade barriers for imports from Canada, because competition from foreign exporters is lowered. ${ }^{16}$ On the other hand, there is nearly no change in total profits of exporting firms. Hence, whenever politicians can be influenced by lobbying activities of firms, there seems to be a good chance for higher import barriers. Domestic firms profit from it, whereas stakes of exporting firms are small. The reason is that the losses incurred due to lower exports are basically offset by gains in sales at the domestic market. ${ }^{17}$ Note that this argumentation is well in line with the "Protection for Sale" literature started by Grossman and Helpman (1994)..$^{18}$

A similar argument can be applied for Canada. Suppose that Canada knows that America will raise trade barriers. This policy would slightly increase profits of domestic firms but decrease profits of exporting firms. What are the effects if Canada raises trade barriers on its own? Again, total profits of exporting firms are more or less unaffected by this policy, since the increases in domestic profits and the losses in exporting profits more or less offset each other. However, domestic firms would gain a great deal from this kind of policy and therefore will make lobbyism in favor of trade barriers. Thus, it seems to be a very plausible outcome that Canada will retaliate.

To sum up, whenever domestic firms that do not export participate in lobbying activities, a government may raise trade barriers in order to gain political support for the next election, as domestic firms gain, whereas exporting firms are not strongly affected. In the end it depends on the lobbying power of firms and the political support whether a government may find it worthwhile to react to negative demand shocks with trade barrier increases. This is true for both, America and Canada. Hence, this argument may rationalize "Buy American"

\footnotetext{
${ }^{16}$ This corresponds to the increase in production along the intensive margin discussed above.

${ }^{17}$ Note that the figure shows relative changes, whereas absolute changes depend on the level of sales at the domestic and foreign market. Hence, even though the relative change is larger for exporting sales, the absolute change is similar in size at the home market and the foreign market, since the level of sales is higher in the home market.

${ }^{18}$ Goldberg and Maggi (1999) as well as Gawande and Bandyopadhyay (2000) find empirical support for the "Protection for Sale" model in the US, even though the weight of contributions in the governments objective function is modest. Grether, de Melo and Olarreaga (2001) applies the "Protection for Sale" model to Mexico, McCalman (2004) to Australia, and Mitra, Thomakos and Ulubasoglu (2002) to Turkey.
} 
and "Buy Canadian" as a retaliation to "Buy American" clauses at the same time.

America
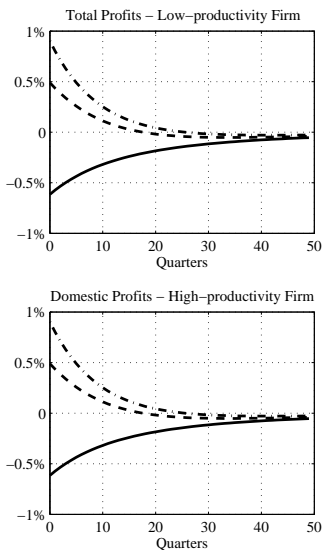
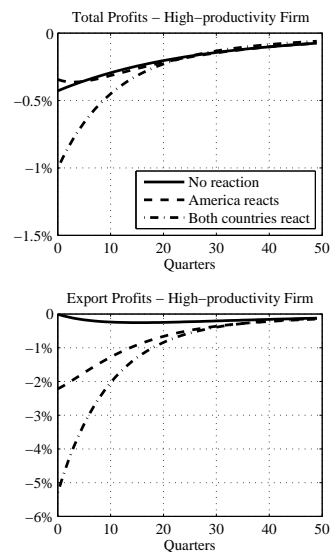

Canada
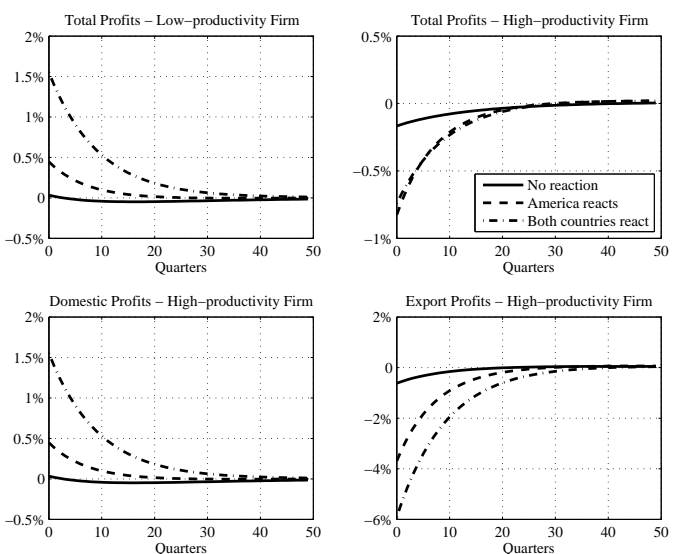

Figure 4: Profits of a low-productivity, non-exporting firm and a highproductivity, exporting firm in response to a demand shock in America for different scenarios.

\subsection{The Role of Openness and Loss Aversion}

International trade implies an interrelationship between countries that leads typically to more volatility in terms of GDP. To give just a recent example, di Giovanni and Levchenko (2009) find a positive and economically significant link between trade openness and volatility. ${ }^{19}$ There is a large literature discussing the link between growth and volatility. To put it with Kose, Prasad and Terrones (2005): "While there appears to be a general consensus that openness to trade flows stimulates domestic growth, it is also the case that such openness increases vulnerability to external shocks."

Exactly the same pattern can be found in our theoretical model. Figure 5 shows how GDP volatility at home, in response to demand and productivity shocks occurring abroad, depends on the level of trade openness. Indeed, the volatility of GDP decreases with the level of trade costs. Hence, the more open countries are, the higher is the volatility of GDP due to shocks occurring in the trading partners. Note, however, that for both countries the level of GDP would be higher with lower trade barriers. Hence, a higher level of welfare is accompanied by a higher degree of volatility in the case of a possibly occurring shock.

\footnotetext{
${ }^{19}$ For additional references to the trade openness and volatility literature please see footnote one in di Givanni and Levchenko (2009). Note that Rancière, Tornell and Westermann (2008) find a similar positive effect of systemic risk in the financial sector on growth.
} 

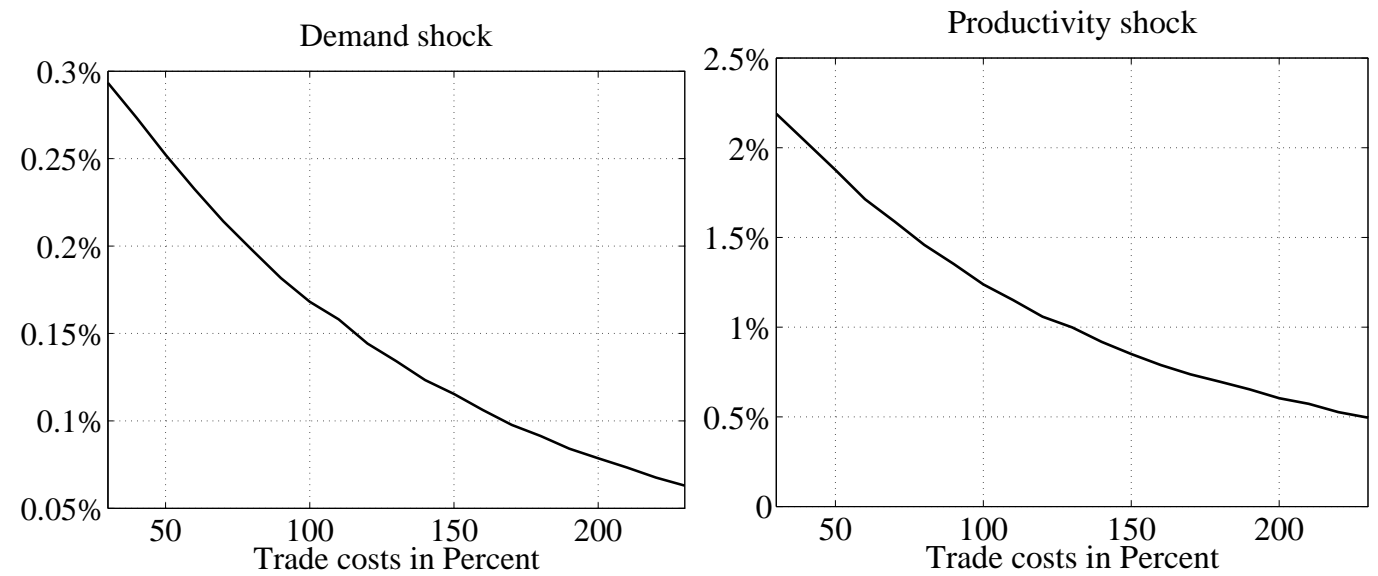

Figure 5: Volatility of GDP (measured as standard deviation and expressed in percent of the mean value of GDP).

Thus, on the one hand globalization brings on average higher income but on the other hand income volatility is increased. As argued in behavioral economics, typically losses are felt more strongly than gains (loss aversion) and people have the tendency to have a stronger preference for more immediate payoffs relative to later payoffs (hyperbolic discounting). This tendency increases the closer to the present both payoffs are. Both facts were demonstrated in many experiments (see for an overview Camerer, Loewenstein, Rabin, 2004; or Wilkinson, 2007). Hence, given loss aversion and hyperbolic discounting, the more immediate losses occurring through the current recession are felt stronger than the potential gains of trade liberalization occurring in the future. It is easy to be pro-globalization when you are in the middle of a boom, enjoying cheap and fancy products from abroad. But if a recession spills over from your trading partner, opinions might change all to quickly. This is very well documented by a recent poll of WorldPublicOpinion.org. ${ }^{20}$ In a poll of 19 countries spread all over the world, a majority of 11 nations is in favor of protectionist measures in the current crisis. Nevertheless, in 16 of 19 nations a majority of people feels that globalization is mostly good. While the results differ a lot between countries, even in the US $42 \%$ are in favor of protectionism. The finance minister of West Bengal Asim Dasgupta seems to agree when he says that the root cause of the present economic crisis lies in globalization. ${ }^{21}$

In light of these results a policymaker might be tempted to react with protectionism in the wake of a crisis. The argument could go like this: We know that trade liberalization is a good idea, increases output and consumption in the long-run (in the steady-state). However, we also know that trade liberalization

\footnotetext{
${ }^{20} \mathrm{http}$ // www.worldpublicopinion.org/pipa/articles/btglobalizationtradera/626.php.

${ }^{21} \mathrm{http}: / /$ www.indianexpress.com/news/minister-blames-globalisation-for-recession/389465/.
} 
increases our vulnerability towards shocks, measured in terms of the volatility of GDP. So why not temporarily increase trade costs when our trading partner is in a crisis (thus reducing our own vulnerability and lowering the volatility of GDP) and drive back trade costs once the crisis is over (thus enjoying the gains from liberal trade)? In this way, we could enjoy the advantages of free trade without suffering the disadvantages. Although certainly not realistic (as this paper tried to demonstrate), in a crisis such a statement might well find its followers.

To sum up, even though overall welfare is reduced by increasing protectionism in both countries, whether the other country reacts or not, there are reasons for which politicians might consider increasing trade barriers as a good idea nevertheless, such as lobbying from firms or loss-aversion leading to an overvaluing of lower volatility as compared to higher (steady-state) welfare levels.

\section{Conclusions}

Recently, political debates about raising trade barriers in order to mitigate the effects of the latest financial crisis took place in many countries around the globe. Trade flows have decreased tremendously during the crisis, mainly because of the recession and not (yet) due to protectionist measures. However, IMF and World Bank, among others, have already noticed an increase in protectionist measures.

We thoroughly analyze the dynamics of transitory changes of trade barriers as a short-run response to an economic downturn in a dynamic, general equilibrium new trade theory model with heterogeneous firms. We show that the beggar-thyneighbor policy does not work. A country cannot shield itself from an economic downturn of its trading partners by temporarily imposing higher trade barriers. It rather hurts itself.

The question then remains why politicians consider protectionism at all. We give two reasons for this. First, firms are hit differently by protectionism. Domestic firms that do not export at all gain in terms of total profits from raising trade barriers, whereas exporting firms are hardly affected. Governments may raise trade barriers in order to support local firms, which may be important campaign contributors and voters in the next election. Second, even though higher trade barriers deter the gains from trade, they mitigate volatility of output when a shock occurs. Hence, whenever people are loss-averse, countries may react with increasing trade barriers in the wake of a crisis in order to reduce volatility of GDP. 


\section{References}

Albuquerque, R., and S. Rebelo (2000): "On the Dynamics of Trade Reform," Journal of International Economics, 51(1), 21-47.

Antràs, P., and R. Caballero (2009): "Trade and Capital Flows: A Financial Frictions Perspective," Journal of Political Economy, 117(4), 701-744.

(2010): "On the Role of Financial Frictions and the Saving Rate during Trade Liberalizations," Journal of the European Economic Association, 8(2-3), 442-445.

Armington, P. (1969): "A Theory of Demand for Products Distinguished by Place of Production," IMF Staff Papers, 16, 159-176.

Bacchetta, P., and H. Dellas (1997): "Firm Restructuring and the Optimal Speed of Trade Reform," Oxford Economic Papers, 49(2), 291-306.

Backus, D., P. Kehoe, and F. Kydland (1992): "International Real Business Cycles," Journal of Political Economy, 100(4), 745-775.

Baldwin, R., And S. Evenett (2009): The Collapse of Global Trade, Murky Protectionism, and the Crisis: Recommendations for the G20. E-book, VoxEU.org.

Bartelsman, E., AND M. Doms (2000): "Understanding Productivity: Lessons from Longitudinal Microdata," Journal of Economic Literature, 38(3), 569-594.

Bernard, A., J. Eaton, J. Jensen, and S. Kortum (2003): "Plants and Productivity in International Trade," American Economic Review, 93(4), 1268-1290.

Bernard, A., And J. Jensen (1995): "Exports, Jobs, and Wages in US Manufacturing: 1976-87," Brookings Papers on Economic Activity: Microeconomics, pp. $67-112$.

(1999): "Exceptional Exporter Performance: Cause, Effect, or Both?," Journal of International Economics, 47(1), 1-25.

(2004): "Why Some Firms Export," Review of Economics and Statistics, 86(2), 561-569.

Bernard, A., J. Jensen, S. Redding, and P. Schott (2007): "Firms in International Trade," Journal of Economic Perspectives, 21(3), 105-130.

(2009): "The Margins of US Trade," American Economic Review Papers and Proceedings, 99(2), 487-493. 
Bouet, A., And D. Laborde (2008): "The Cost of a Non-Doha," IFPRIR Briefing Note.

BrŮHA, J., And J. Podpiera (2007): "Inquiries on Dynamics of Transition Economy Convergence in a Two-Country Model," European Central Bank Working Paper Series No. 791.

Camerer, C., G. Loewenstein, and M. Rabin (eds.) (2004): Advances in Behavioral Economics. Princeton University Press, Princeton and Oxford.

Chaney, T. (2008): "Distorted Gravity: The Intensive and Extensive Margins of International Trade," American Economic Review, 98(4), 1707-1721.

Clerides, S., S. Lach, And J. Tybout (1998): "Is Learning by Exporting Important? Micro-Dynamic Evidence from Columbia, Mexico, and Morocco," Quarterly Journal of Economics, 113(3), 903-947.

Costantini, J., and M. Melitz (2007): "The Dynamics of Firm Level Adjustment to Trade Liberalization," unpublished manuscript.

Davis, S., and J. Haltiwanger (1992): "Gross Job Creation, Gross Job Destruction, and Employment Reallocation," Quarterly Journal of Economics, 107(3), 819-863.

Di Giovanni, J., And A. Levchenko (2009): "Trade Openness and Volatility," Review of Economics and Statistics, 91(3), 558-585.

Dunne, T., M. Roberts, and L. Samuelson (1989): "The Growth and Failure of U.S. Manufacturing Plants," Quarterly Journal of Economics, 104(4), 671-698.

Erixon, F. (2009): "Protectionism is on the Rise," VoxEU.org.

Feenstra, R. (2004): Advanced International Trade: Theory and Evidence. Princeton University Press, Princeton, New Jersey.

Furusawa, T., And E. Lai (1999): "Adjustment Costs and Gradual Trade Liberalization," Journal of International Economics, 49(2), 333-361.

Galí, J., J. D. López-Salido, and J. Vallés (2007): "Understanding the Effects of Government Spending on Consumption," Journal of the European Economic Association, 5(1), 227-270.

Gali, J. (2008): Monetary Policy, Inflation, and the Business Cycle. Princeton University Press, Princeton, New Jersey.

Gamberoni, E., and R. Newfarmer (2009): "Trade Protection: Incipient but Worrisome Trends," VoxEU.org. 
Gawande, K., and U. Bandyopadhyay (2000): "Is Protection For Sale? A Test of the Grossman-Helpman Theory of Endogenous Protection," Review of Economics and Statistics, 82(1), 139-152.

Ghironi, F. (2006): "Macroeconomic Interdependence under Incomplete Markets," Journal of International Economics, 70(2), 428-450.

Ghironi, F., And M. Melitz (2005): "International Trade and Macroeconomic Dynamics with Heterogeneous Firms," Quarterly Journal of Economics, 120(3), 865-915.

Goldberg, P., and G. Maggi (1999): "Protection for Sale: An Empirical Investigation," American Economic Review, 89(5), 1135-1155.

Gregory, R., C. Henn, B. McDonald, and M. Saito (2010): "Trade and the Crisis: Protect or Recover," IMF Staff Position Note, 1007.

Grether, J.-M., J. De Melo, and M. Olarreaga (2001): "Who Determine Mexican Trade Policy?," Journal of Development Economics, 64(2), 343-370.

Grossman, G., and E. Helpman (1991): Innovation and Growth in the Global Economy. The MIT Press, Cambridge, Massachusetts.

850.

(1994): "Protection for Sale," American Economic Review, 84(4), 833-

Helpman, E., M. Melitz, and Y. Rubinstein (2008): "Trading Partners and Trading Volumes," Quarterly Journal of Economics, 123(2), 441-487.

Hufbauer, G., And J. Schotт (2009): "Buy American: Bad for Jobs, Worse for Reputation," Peterson Institute for International Economics Policy Brief.

IMF And World Bank (2009): Global Monitoring Report 2009: A Development Emergency. Washington, CD.

Kose, M., E. Prasad, and M. Terrones (2005): "How Do Trade and Financial Integration Affect the Relationship between Growth and Volatility?," IMF Working Paper WP/05/19.

Kumar, S. (2009): "Protectionism: What are the Options?," VoxEU.org.

Leamer, E. (1980): "Welfare Computations and the Optimal Staging of Tariff Reductions in Models with Adjustment Costs," Journal of International Economics, 10(1), 21-36.

Lewis, V. (2009): "Business Cycle Evidence on Firm Entry," Macroeconomic Dynamics, 13(5), 605-624. 
McCalman, P. (2004): "Protection for Sale and Trade Liberalization: An Empirical Investigation," Review of International Economics, 12(1), 81-94.

Melitz, M. (2003): "The Impact of Trade on Intra-Industry Reallocations and Aggregate Industry Productivity," Econometrica, 71(6), 1695-1725.

Mitra, D., D. Thomakos, and M. Ulubasoglu (2002): "Protection for Sale' In A Developing Country: Democracy versus Dictatorship," Review of Economics and Statistics, 84(3), 497-508.

Mussa, M. (1986): The Adjustment Process and the Timing of Trade Liberalization. in: Choksi, A.M., Papageorgiou, D. (Eds.), Economic Liberalization in Developing Countries. Basil Blackwell, New York.

Obstfeld, M., and K. Rogoff (2001): The Six Major Puzzles in International Macroeconomics: Is There a Common Cause? in: Ben S. Bernanke and Kenneth S. Rogoff (Eds.), NBER Macroeconomics Annual 2000, Cambridge, MA: MIT Press.

Rancière, R., A. Tornell, and F. Westermann (2008): "Systemic Crises and Growth," Quarterly Journal of Economics, 123(1), 359-406.

Roberts, M., and J. Tybout (1997): "The Decision to Export in Colombia: An Empirical Model of Entry with Sunk Costs," American Economic Review, $87(4), 545-564$.

Staiger, R. (1995): A Theory of Gradual Trade Liberalization. in: Levinsohn, J., Deardorff, A.V., Stern, R.M. (Eds.), New Directions in Trade Theory. University of Michigan Press, Ann Arbor, MI.

Uhilg, H. (2010): "Some Fiscal Calculus," American Economic Review, 100(2), $30-34$.

Wilkinson, N. (2007): An Introduction to Behavioral Economics: A Guide for Students. Palgrave Macmillan, United Kingdom. 


\title{
Technical Appendix to:
}

\section{Why "Buy American" is a Bad Idea but Politicians Still Like It}

\author{
Mario Larch ${ }^{\dagger}$, Wolfgang Lechthaler ${ }^{\ddagger}$
}

October 8, 2010

\footnotetext{
${ }^{\dagger}$ University of Bayreuth, Ifo Institute for Economic Research at the University of Munich and CESifo, Universitaetsstrasse 30, 95447 Bayreuth, Germany. E-mail: mario.larch@unibayreuth.de.

${ }^{\ddagger}$ Kiel Institute for the World Economy, Duesternbrooker Weg 120, D-24105 Kiel, Germany. E-mail: wolfgang.lechthaler@ifw-kiel.de
} 
This Technical Appendix provides more discussion about the changes at the intensive and extensive margin in Section A1, more robustness checks of key model parameters in Section A2, a detailed description of the theoretical model in Section A3, as well as a more thorough discussion of the calibration of the model in Section A4.

In Section A2 we provide robustness checks concerning the elasticity of substitution (Subsection A2.1), the rate of firm-breakdown (Subsection A2.2), the steady-state trade costs (Subsection A2.3), and the timing of retaliation (Subsection A2.4).

The model description given in Section A3 is subdivided into the presentation of the household preferences and intratemporal choices in Subsection A3.1, the production, pricing, and export decisions in Subsection A3.2, the averages of key firm characteristics in Subsection A3.3, the important firm entry and export decisions in Subsection A3.4, the household budget constraint and intertemporal choices in Subsection A3.5, and the closing of the model, i.e., the aggregate accounting and labor market clearing, in Subsection A3.6.

The calibration of the model described in Section A4 is subdivided into the parametrization of the productivity draws (Subsection A4.1), and the parametrization of preferences and costs (Subsection A4.2). 


\section{A1 More on Changes at the Intensive and Ex- tensive Margin}
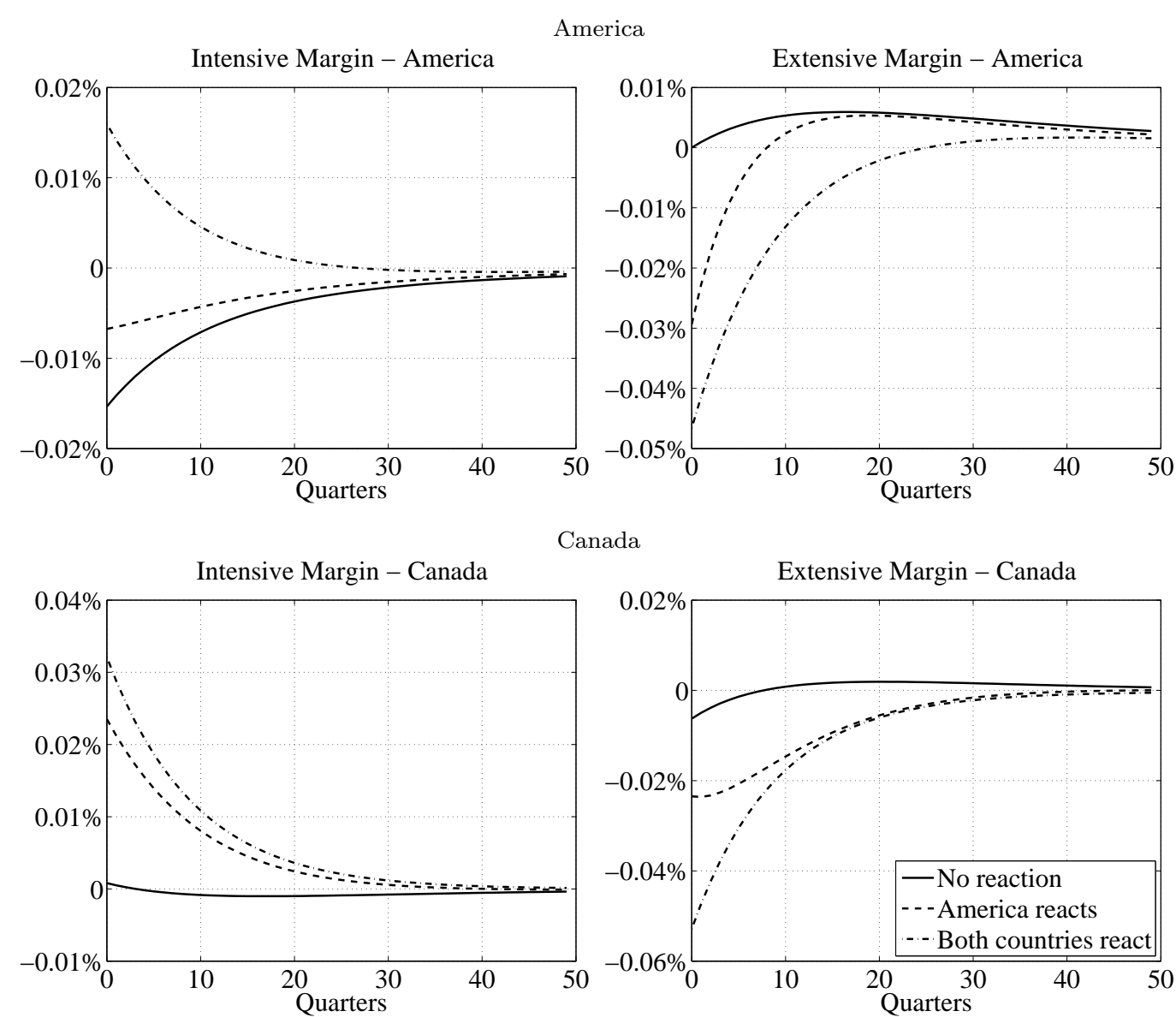

Canada

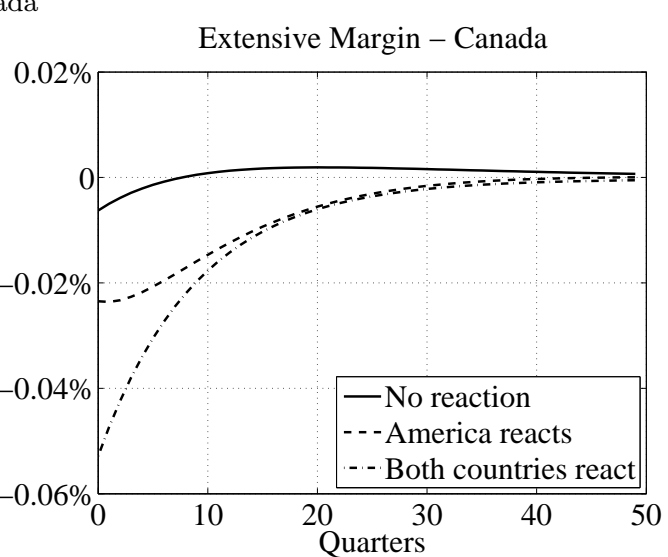

Figure A1: Changes at the intensive and extensive margin.

In this section we discuss in more detail the results of Subsection 3.4. Hence, we have a closer look at the effects of demand shocks and trade policy changes at the extensive and intensive margin.

First, note that as discussed in the main text, consumption and GDP fall for all time periods and all three scenarios considered, the only exception being the Buy American scenario with a positive increase in GDP for the short-run when compared to the situation without policy reaction (see Table 1). Without policy response a sharp drop at the intensive margin occurs (see Figure A1), whereas there is a moderate increase at the extensive margin. The reason is that a negative demand shock directly affects demand for every variety negatively. Hence, the amount sold per variety falls, which is the change at the intensive margin. On the other hand, lower demand for each variety leads to less pressure on the labor 
market, a fall in wages, leading to lower entry costs into the market. This leads to firm entry and a slight increase at the extensive margin.

As soon as America reacts to the demand shock by increasing trade barriers, the effects on the intensive margin are mitigated, as can be seen by the positive change reported in the table. This result holds for all time spans investigated. The reason is that domestic varieties become relatively more attractive compared to foreign varieties, counteracting the initial negative demand shock. However, shielding domestic firms from foreign competition leads to less competition, higher prices, and mitigates the incentive to enter the market. Hence, the lower negative drop at the intensive margin comes at the cost of a larger drop at the extensive margin, as indicated by negative effects for the change in the extensive margin.

For Canada a demand shock in America combined with increasing trade barriers for imports of Canadian products to America also leads to an increase at the intensive margin and a drop at the extensive margin as compared to the initial situation without policy intervention (see again Figure A1). The reason is that the negative demand shock lowers the export demand for Canadian varieties. Hence, as a response, less exporting firms will be able to survive, leading to a drop at the extensive margin. Due to fewer exporting firms, already existing less productive domestic firms can sell more. This explains the increase at the intensive margin.

What happens if Canada reacts to the increase in trade barriers for products imported from America by an equal increase in trade barriers for American products sold in Canada? For America we see an increase at the intensive margin in this case (reflected by a large positive change). Whereas the drop in demand due to the demand shock reduces the change at the intensive margin, the trade barrier increase reduces the drop. Hence, retaliation by Canada even shifts more of the demand to home firms. This leads to larger firms, i.e., an increase at the intensive margin. At the extensive margin we see again a drop in the number of firms, as in the case of unilateral trade barrier changes, which is larger than in all other scenarios. Similarly, in Canada the intensive margin increases and the extensive margin decreases, as was the case when only America changed trade barriers. However, the effects on both, the intensive and extensive margin are stronger when Canada also increases trade barriers. The reason is that the shift induced to domestic firms due to changing relative prices as well as the decrease in competition, magnifies the decrease in the number of exporting firms and increases the size of the average firm. 


\section{A2 Robustness Checks}

We infer in this section robustness concerning the most important parameters of our model. Specifically, we provide evidence of different levels of the elasticity of substitution in Subsection A2.1, the rate of firm-breakdown in Subsection A2.2, the steady-state trade costs in Subsection A2.3, and the scenario of retaliation in Subsection A2.4.

\section{A2.1 The Elasticity of Substitution $(\theta)$}

The elasticity of substitution has, as in every new trade theory model, two important roles: On the one hand it determines how willing consumers are to exchange different varieties against each other, and on the other hand it directly determines the mark-up on marginal costs of producers. Hence, the elasticity of substitution is a key parameter.

Figure A2 shows the drop in consumption due to protectionism, i.e. a short term increase in trade costs by America, for three different levels of the elasticity of substitution $\theta$ for both, America and Canada.

America

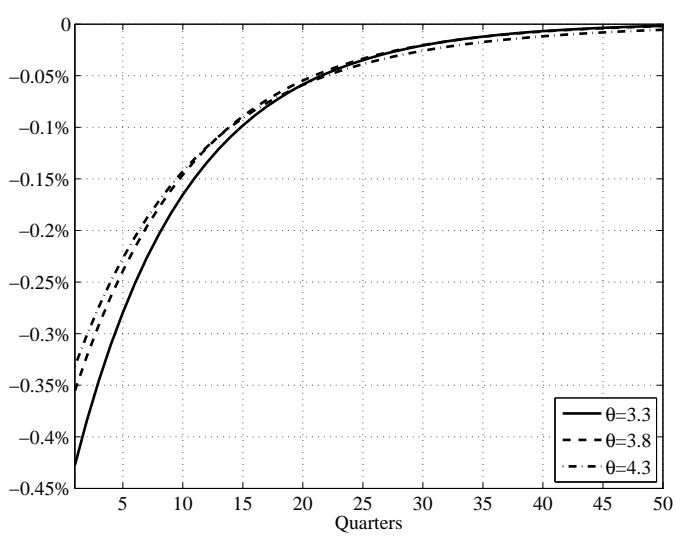

Canada

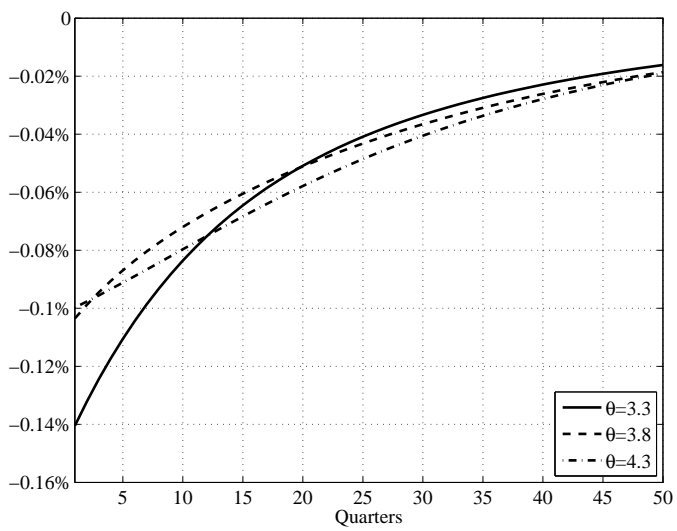

Figure A2: Drop in consumption due to protectionism in dependence of the elasticity of substitution $(\theta)$.

As can be seen, the qualitative effects of protectionism remain the same, while the quantitative impact changes only a little bit. A higher elasticity of substitution lowers the drop in consumption for America and Canada in the first few periods, whereas it is slightly increased in later periods. This result can be explained as follows.

Protectionism increases the relative price of foreign varieties as compared to domestic varieties. With a higher elasticity of substitution consumers are more willing to switch from more expensive foreign varieties to domestic varieties. Hence, the overall level of consumption is not so heavily affected. Additionally, 
with a higher elasticity of substitution product markets are more competitive and firms have a lower mark-up. Hence, increasing protectionism is not so harmful for consumers as product markets are already quite competitive. If the elasticity of substitution is low, additional shielding of domestic firms from foreign competition leads to even higher prices and therefore a larger drop in consumption. 


\section{A2.2 The Rate of Firm-Breakdown $(\delta)$}

As we argued in the main text, churning at both, the extensive and intensive margin, is important in order to understand our results of changes in short-term trade policy as a response to a demand shock. In order to allow changes at both margins, we used a dynamic version of the Melitz (2003) model based on Ghironi and Melitz (2005). In line with these models, we assumed an exogenous rate of firm-breakdown $\delta$.

The firm-breakdown has several important effects. On the one hand it drives out inefficient firms from the market. On the other hand it uses up resources, as new firms have again to incur fixed costs in order to start production. Hence, one may wonder how the drop in consumption is affected due to protectionism for different levels of firm-breakdown $\delta$. Figure A3 gives the answer.

America

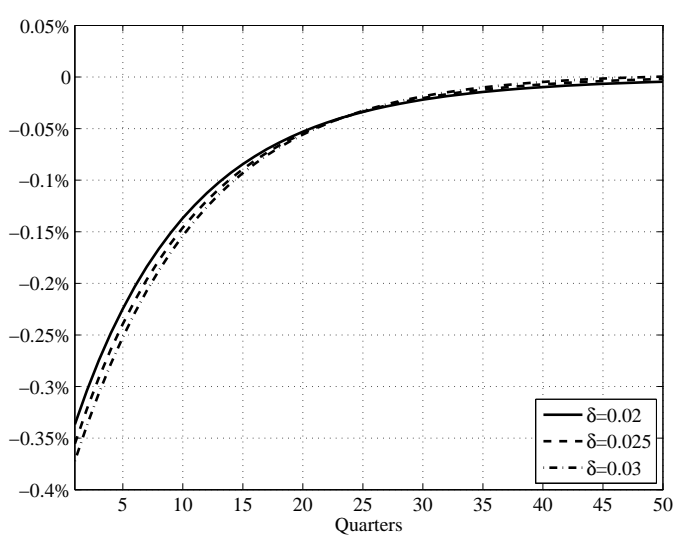

Canada

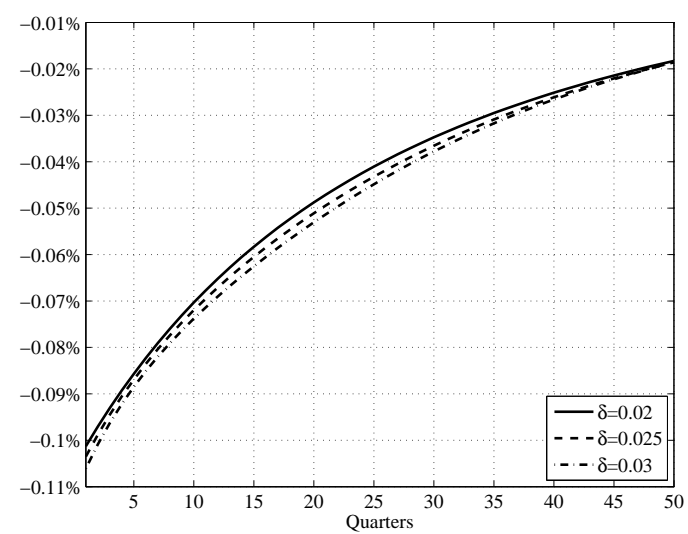

Figure A3: Drop in consumption due to protectionism in dependence of the rate of firm-breakdown $(\delta)$.

First, note that the effects are small for both, America and Canada. Second, in both countries a higher level of firm-breakdown means a sharper drop in consumption after protectionism in the first periods, whereas a very modest lower drop can be seen in the later periods. This result can be explained by the fact that a larger rate of firm-breakdown allows for a more rapid adjustment in the economy, leading to a faster exchange of more productive exporting firms by less productive domestic firms. Hence, the drop in consumption is larger in the first periods. 


\section{A2.3 The Steady-State Trade Costs $(\tau)$}

In this subsection we investigate the drop in consumption due to protectionism, i.e. the short-term change of trade costs by America, for various levels of steadystate trade $\operatorname{costs} \tau$. Figure A4 displays the results.
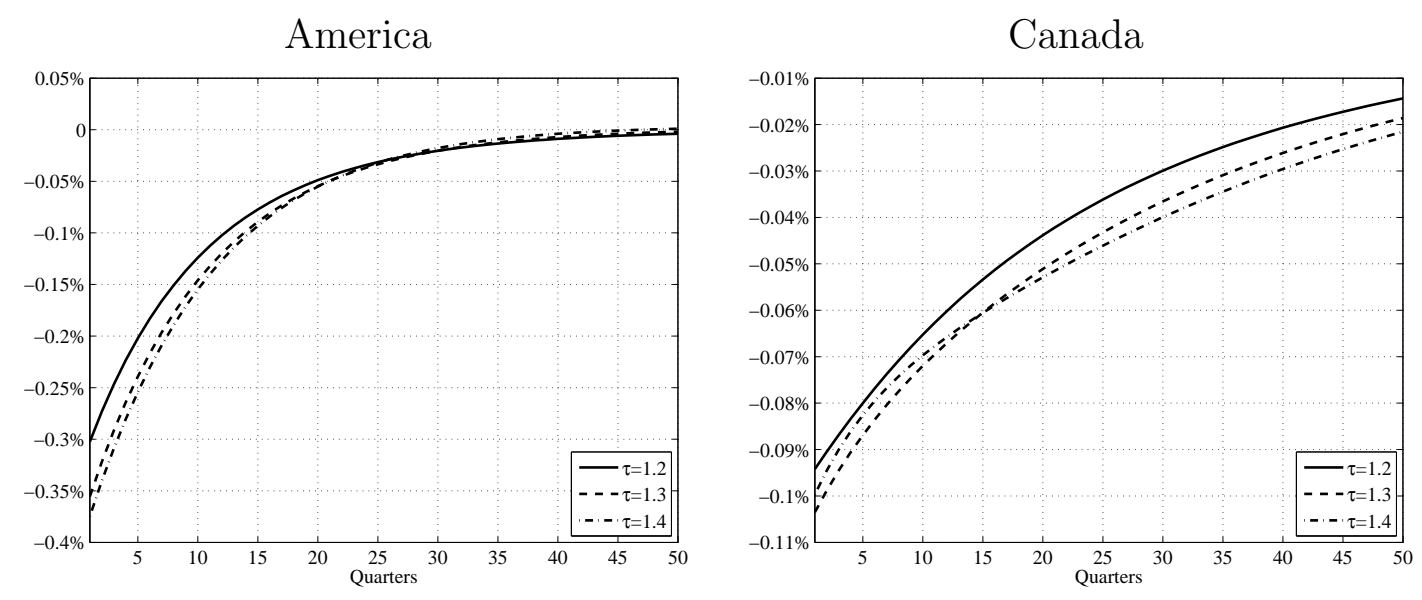

Figure A4: Drop in consumption due to protectionism in dependence of steadystate trade costs $(\tau)$.

Again, qualitatively our results stay the same and even the quantitative impact is very small. As can be seen, on impact higher steady-state trade costs lead to larger drops in consumption for both countries after a temporary increase of trade barriers by America. The reason is that we considered relative temporary changes in trade costs, implying that the temporary increase in trade costs is larger for higher values of steady-state trade costs.

If we would investigate an equal short-term change of trade barriers for different levels of steady-state trade costs, the decrease of consumption is higher for more open economies (not displayed). The reason is that more open countries have higher levels of trade volumes that are affected by a temporary increase in trade barriers. 


\section{A2.4 The Timing of Retaliation}

In Subsection 3.3 we investigated how responses of GDP, consumption and the trade balance vary, when Canada immediately reacts to the temporary increase in trade barriers of America by raising trade barriers on its own. In this robustness section we extend the analysis and allow Canada to react with delay.
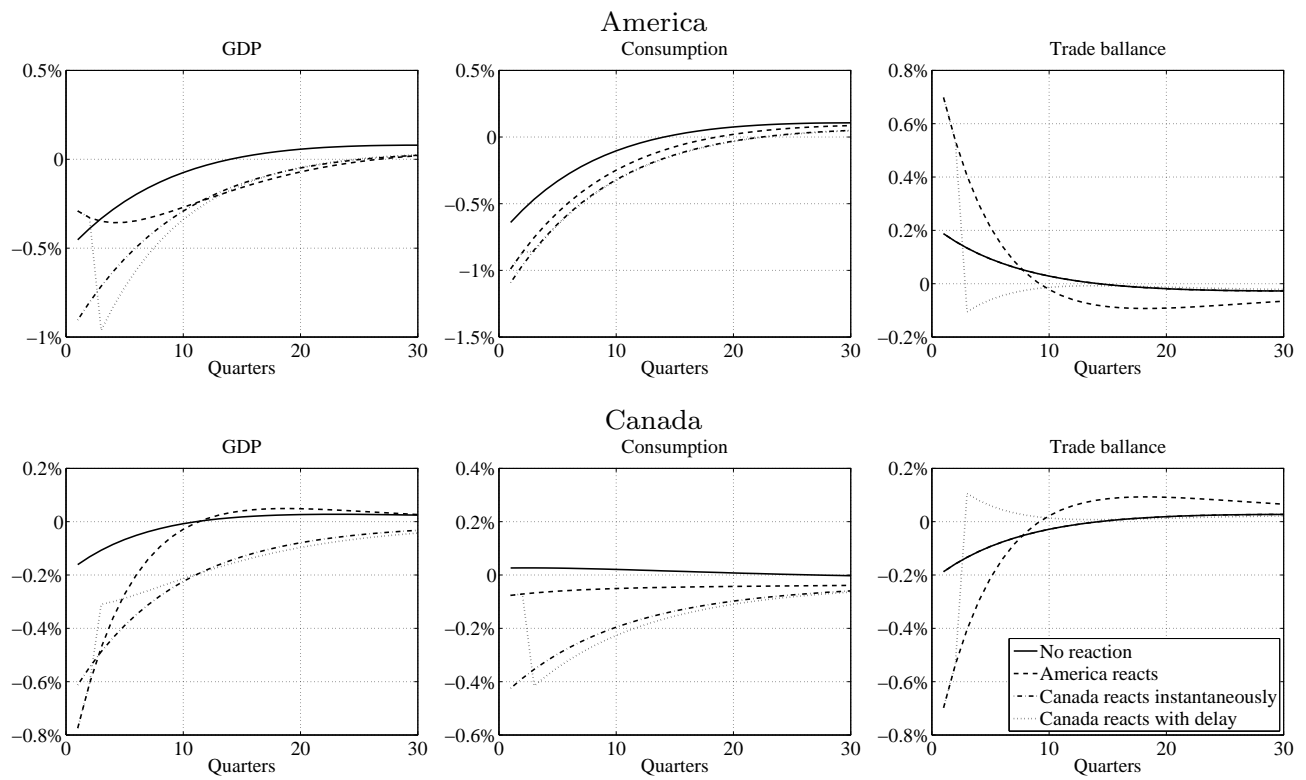

Figure A5: Retaliation: both countries raise trade barriers.

What we can see here is that the delay does not change any of our qualitative results. Basically, when country 2 reacts with delay, the change in GDP and consumption is equal to the case when country 2 would not react at all for the periods until it reacts. Afterwards, there is a smooth adjustment to the path we observed when country 2 reacted in the same period.

Hence, whether we assume that Canada changes the trade barriers in the same period as America or not, does not affect any of our results qualitatively. 


\section{A3 The Model}

In this section we describe the model framework introduced in Ghironi and Melitz (2005) allowing for international trade in bonds.

\section{A3.1 Household Preferences and Intratemporal Choices}

We assume two countries, labeled home and foreign. Foreign variables are denoted by an asterisk. Each country is populated by a unit mass of atomistic households. Prices are in nominal terms and flexible. In the following, we only solve for the real variables. However, as the composition of consumption baskets in the two countries changes over time, which affects the definitions of the consumptionbased price indexes, money is introduced as a convenient unit of account for contracts. However, as money plays no other role, the demand for cash currency is not modeled, following Ghironi and Melitz (2005).

The representative home (foreign) household supplies $L\left(L^{*}\right)$ units of labor inelastically in each period at the nominal wage rate $W_{t}\left(W_{t}^{*}\right)$, denominated in units of the home (foreign) currency. Every household maximizes expected intertemporal utility from consumption (C): $E_{t}\left[\sum_{s=t}^{\infty} \beta^{s-t} C_{s}^{1-\gamma} /(1-\gamma)\right]$, where $\beta \in(0,1)$ is the subjective discount factor and $\gamma>0$ is the inverse of the intertemporal elasticity of substitution. At time $t$, the household consumes the basket of goods $C_{t}$, defined over a continuum of goods $\Omega: C_{t}=\left(\int_{\omega \in \Omega} c_{t}(\omega)^{(\theta-1) / \theta} d \omega\right)^{\theta /(\theta-1)}$, where $\theta>1$ is the elasticity of substitution across goods. Note that only a subset of goods $\Omega_{t} \subset \Omega$ is available at any given time $t$. We denote $p_{t}(\omega)$ the home currency price of a good $\omega \in \Omega_{t}$. The consumption-based price index for the home economy is then $P_{t}=\left(\int_{\omega \in \Omega_{t}} p_{t}(\omega)^{1-\theta} d \omega\right)^{1 /(1-\theta)}$, and the household's demand for each individual good $\omega$ is given by $c_{t}(\omega)=\left(p_{t}(\omega) / P_{t}\right)^{-\theta} C_{t}$. Additionally, aggregate demand comprises an exogenously given part $\bar{C}$, which has the same composition as $C$.

We assume that the foreign country (Canada) has identical parameters, leading to a similar price index and demand function. However, the subset of goods available for consumption in the foreign economy during period $t$ is $\Omega_{t}^{*} \subset \Omega$ and can differ from the subset of goods that are available in the home economy.

\section{A3.2 Production, Pricing, and the Export Decision}

There is a continuum of firms in each country, each producing a different variety $\omega \in \Omega$. There is only one factor of production, labor. Aggregate labor productivity is indexed by $Z_{t}\left(Z_{t}^{*}\right)$, which represents the effectiveness of one unit of home (foreign) labor. Firms are heterogeneous with respect to their unit cost of production, following Melitz (2003), where a home firm with relative productivity $z$ produces $Z_{t} z$ units of output per unit of labor employed. Hence, the unit cost 
of production, measured in units of the consumption good $C_{t}$, is $w_{t} /\left(Z_{t} z\right)$, where $w_{t} \equiv W_{t} / P_{t}$ is the real wage. Similarly, unit costs of production for foreign firms are given by $w_{t}^{*} /\left(Z_{t}^{*} z\right)$, where $w_{t}^{*} \equiv W_{t}^{*} / P_{t}^{*}$ is the real wage of foreign workers.

Before entering the market firms have to incur a sunk entry cost of $f_{E, t}\left(f_{E, t}^{*}\right)$ effective labor units, equal to $w_{t} f_{E, t} / Z_{t}\left(w_{t}^{*} f_{E, t}^{*} / Z_{t}^{*}\right)$ units of the home (foreign) consumption good. Upon entry, firms at home and abroad draw their productivity level $z$ from a common distribution $G(z)$ with support on $\left[z_{\min }, \infty\right)$, which stays constant thereafter. In contrast to Melitz (2003) there are no fixed production costs, which implies that all firms produce in every period. Every firm may be hit by a "death" shock, which occurs with probability $\delta \in(0,1)$ in each period. It is assumed that this exit-inducing shock is independent of the firm's productivity level, so $G(z)$ also represents the productivity distribution of all producing firms.

Beside serving the domestic market, a firm may export. Exporting involves variable iceberg trade $\operatorname{cost} \tau_{t} \geq 1\left(\tau_{t}^{*} \geq 1\right)$ as well as period-by-period fixed costs $f_{X, t}\left(f_{X, t}^{*}\right)$ (measured in units of effective labor). Both, variable and fixed costs are covered by domestic labor. These costs, in real terms and unit of the home (foreign) consumption good, are then $w_{t} f_{X, t} / Z_{t}\left(w_{t}^{*} f_{X, t}^{*} / Z_{t}^{*}\right)$ for home (foreign) firms.

Given the demand function with constant elasticity $(\theta)$ and monopolistic competition, optimal pricing behavior of all firms is given by a constant markup $\theta /(\theta-1)$ over marginal cost. Let $p_{D, t}(z)$ and $p_{X, t}(z)$ denote the nominal domestic and export prices of a home firm, where the export prices are denominated in the currency of the export market. Prices, in real terms relative to the price index in the destination market, are then given by

$$
\rho_{D, t}(z) \equiv \frac{p_{D, t}(z)}{P_{t}}=\frac{\theta}{\theta-1} \frac{w_{t}}{Z_{t} z}, \quad \rho_{X, t}(z) \equiv \frac{p_{X, t}(z)}{P_{t}^{*}}=Q_{t}^{-1} \tau_{t} \rho_{D, t}(z),
$$

where $Q_{t} \equiv \varepsilon_{t} P_{t}^{*} / P_{t}$ is the consumption-based real exchange rate, i.e., units of home consumption per unit of foreign consumption, where $\varepsilon_{t}$ is the nominal exchange rate in units of home currency per unit of the foreign currency.

Due to the fixed export cost, firms with low productivity levels $z$ may decide not to export. Total profits $d_{t}(z)\left(d_{t}^{*}(z)\right)$ are distributed to households as dividends and expressed in terms of the home consumption basket. They are given by $d_{t}(z)=d_{D, t}(z)+d_{X, t}(z)$, where

$$
\begin{aligned}
& d_{D, t}(z)=\frac{1}{\theta}\left[\rho_{D, t}(z)\right]^{1-\theta}\left(C_{t}+\bar{C}_{t}\right) \\
& d_{X, t}(z)= \begin{cases}\frac{Q t}{\theta}\left[\rho_{X, t}(z)\right]^{1-\theta}\left(C_{t}^{*}+\bar{C}_{t}^{*}\right)-\frac{w_{t} f_{X, t}}{Z_{t}} & \text { if firm } z \text { exports } \\
0 & \text { otherwise }\end{cases}
\end{aligned}
$$

Foreign firms behave in a similar way. As in Melitz (2003), more productive firms earn higher profits (relative to less productive firms) and set lower prices (see equation (A1)). A home (foreign) firm will export when productivity $z$ is 
above a cutoff level $z_{X, t}=\inf \left\{z: d_{X, t}(z)>0\right\}\left(z_{X, t}^{*}=\inf \left\{z: d_{X, t}^{*}(z)>0\right\}\right)$. The lower bound productivity $z_{\min }$ is assumed to be low enough relative to the export costs so that $z_{X, t}$ and $z_{X, t}^{*}$ are both above $z_{\text {min }}$. This ensures that firms with productivity levels between $z_{\min }$ and $z_{X, t}\left(z_{X, t}^{*}\right)$ decide not to export. Note that this set of firms as well as $z_{X, t}$ and $z_{X, t}^{*}$ fluctuates over time with changes in the profitability of the export market.

\section{A3.3 Firm Averages}

In every period, a mass $N_{D, t}\left(N_{D, t}^{*}\right)$ of firms produces in America (Canada). These firms have a distribution of productivity levels over $\left[z_{\min }, \infty\right)$ given by $G(z)$. Among these firms, there are $N_{X, t}=\left[1-G\left(z_{X, t}\right)\right] N_{D, t}$ and $N_{X, t}^{*}=\left[1-G\left(z_{X, t}^{*}\right)\right] N_{D, t}^{*}$ exporters. Following Melitz (2003), we define two special "average" productivity levels - an average $\tilde{z}_{D}$ for all producing firms (in each country), and an average $\tilde{z}_{X, t}$ for all home exporters:

$$
\tilde{z}_{D} \equiv\left[\int_{z_{\min }}^{\infty} z^{\theta-1} d G(z)\right]^{\frac{1}{\theta-1}}, \quad \tilde{z}_{X, t} \equiv\left[\frac{1}{1-G\left(z_{X, t}\right)} \int_{z_{X, t}}^{\infty} z^{\theta-1} d G(z)\right]^{\frac{1}{\theta-1}} .
$$

(The definition of $\tilde{z}_{X, t}^{*}$ is analogous to that of $\tilde{z}_{X, t}$.) As shown in Melitz (2003), these productivity averages - based on weights proportional to relative firm output shares - summarize all the information about the productivity distributions which is relevant for the macroeconomic variables. In essence, this implies that the model is isomorphic to one where $N_{D, t}\left(N_{D, t}^{*}\right)$ firms with productivity level $\tilde{z}_{D}$ produce in America (Canada) and $N_{X, t}\left(N_{X, t}^{*}\right)$ firms with productivity level $\tilde{z}_{X, t}\left(\tilde{z}_{X, t}^{*}\right)$ export to the foreign (home) market.

In particular, $\tilde{p}_{D, t} \equiv p_{D, t}\left(\tilde{z}_{D}\right)\left(\tilde{p}_{D, t}^{*} \equiv p_{D, t}^{*}\left(\tilde{z}_{D}\right)\right)$ represents the average nominal price of home (foreign) firms in their domestic market, and $\tilde{p}_{X, t} \equiv p_{X, t}\left(\tilde{z}_{X, t}\right)\left(\tilde{p}_{X, t}^{*} \equiv\right.$ $\left.p_{X, t}^{*}\left(\tilde{z}_{X, t}^{*}\right)\right)$ represents the average nominal price of home (foreign) exporters in the export market. The price index at home reflects the prices of the $N_{D, t}$ home firms (with average price $\tilde{p}_{D, t}$ ) and the $N_{X, t}^{*}$ foreign exporters to the home market (with average price $\tilde{p}_{X, t}^{*}$ ). The home price index can thus be written as $P_{t}=\left[N_{D, t}\left(\tilde{p}_{D, t}\right)^{1-\theta}+N_{X, t}^{*}\left(\tilde{p}_{X, t}^{*}\right)^{1-\theta}\right]^{1 /(1-\theta)}$. This is equivalent to $N_{D, t}\left(\tilde{\rho}_{D, t}\right)^{1-\theta}+$ $N_{X, t}^{*}\left(\tilde{\tilde{\rho}}_{X, t}^{*}\right)^{1-\theta}=1$, where $\tilde{\rho}_{D, t} \equiv \rho_{D, t}\left(\tilde{z}_{D}\right)$ and $\tilde{\rho}_{X, t}^{*} \equiv \rho_{X, t}^{*}\left(\tilde{z}_{X, t}^{*}\right)$ represent the average relative prices of home producers and foreign exporters in the home market. Similar equations hold for the foreign price index.

The productivity averages $\tilde{z}_{D}, \tilde{z}_{X, t}$, and $\tilde{z}_{X, t}^{*}$ are constructed in such a way that $\tilde{d}_{D, t} \equiv d_{D, t}\left(\tilde{z}_{D}\right)\left(\tilde{d}_{D, t}^{*} \equiv d_{D, t}^{*}\left(\tilde{z}_{D}\right)\right)$ represents the average firm profit earned from domestic sales for all home (foreign) producers; and $\tilde{d}_{X, t} \equiv d_{X, t}\left(\tilde{z}_{X, t}\right)\left(\tilde{d}_{X, t}^{*} \equiv\right.$ $\left.d_{X, t}^{*}\left(\tilde{z}_{X, t}^{*}\right)\right)$ represents the average firm export profits for all home (foreign) exporters. Thus, $\tilde{d}_{t} \equiv \tilde{d}_{D, t}+\left[1-G\left(z_{X, t}\right)\right] \tilde{d}_{X, t}$ and $\tilde{d}_{t}^{*} \equiv \tilde{d}_{D, t}^{*}+\left[1-G\left(z_{X, t}^{*}\right)\right] \tilde{d}_{X, t}^{*}$ represent the average total profits of home and foreign firms, since $1-G\left(z_{X, t}\right)$ 
and $1-G\left(z_{X, t}^{*}\right)$ represent the proportion of home and foreign firms that export and earn export profits.

\section{A3.4 Firm Entry and Exit}

In every period there is an unbounded mass of prospective entrants in both countries. These entrants are forward looking, and correctly anticipate their future expected profits $\tilde{d}_{t}\left(\tilde{d}_{t}^{*}\right)$ in every period (the preentry expected profit is equal to postentry average profit) as well as the probability $\delta$ (in every period) of incurring the exit-inducing shock. Entrants at time $t$ only start producing at time $t+1$, which introduces a one-period time-to-build lag in the model. The exogenous exit shock occurs at the very end of the time period (after production and entry). A proportion $\delta$ of new entrants will therefore never produce. Home entrants in period $t$ compute their expected postentry value given by the present discounted value of their expected stream of profits $\left\{\tilde{d}_{s}\right\}_{s=t+1}^{\infty}$ :

$$
\tilde{v}_{t}=E_{t} \sum_{s=t+1}^{\infty}[\beta(1-\delta)]^{s-t}\left(\frac{C_{s}}{C_{t}}\right)^{-\gamma} \tilde{d}_{s} .
$$

This also represents the average value of incumbent firms after production has occurred, since both new entrants and incumbents then face the same probability $1-\delta$ of survival and production in the subsequent period. Firms discount future profits using the household's stochastic discount factor, adjusted for the probability of firm survival $1-\delta$. Entry occurs until the average firm value is equalized with the entry cost, leading to the free entry condition $\tilde{v}_{t}=w_{t} f_{E, t} / Z_{t}$. This condition holds as long as the mass $N_{E, t}$ of entrants is positive. Following Ghironi and Melitz (2005), it is assumed that macroeconomic shocks are small enough for this condition to hold in every period. Finally, the timing of entry and production we have assumed implies that the number of home-producing firms during period $t$ is given by $N_{D, t}=(1-\delta)\left(N_{D, t-1}+N_{E, t-1}\right)$. A similar free entry condition, requirements for the size of shocks, and law of motion for the number of producing firms hold in Canada.

\section{A3.5 Household Budget Constraint and Intertemporal Choices}

Households in each country hold two types of assets: shares in a mutual fund of domestic firms and domestic and foreign risk-free bonds. Bonds at home and abroad pay risk-free, consumption-based real returns. $x_{t}$ denotes the share in the mutual fund of home firms held by the representative home household entering period $t$. The mutual fund pays a total profit in each period (in units of the home currency) that is equal to the average total profit of all home firms that produce in that period, $P_{t} \tilde{d}_{t} N_{D, t}$. During period $t$, the representative home household buys 
$x_{t+1}$ shares in a mutual fund of $N_{H, t}=N_{D, t}+N_{E, t}$ home firms (those already operating at time $t$ and the new entrants). Only $N_{D, t+1}=(1-\delta) N_{H, t}$ firms will produce and pay dividends at time $t+1$. Since the household does not know which firms will be hit by the exogenous exit shock $\delta$, it finances the continuing operation of all preexisting home firms and all new entrants during period $t$. The date $t$ price (in units of home currency) of a claim to the future profit stream of the mutual fund of $N_{H, t}$ firms is equal to the average nominal price of claims to future profits of home firms, $P_{t} \tilde{v}_{t}$.

The home household enters period $t$ with home (foreign) bond holdings $B_{t}$ $\left(B_{*, t}\right)$ in units of consumption and mutual fund share holdings $x_{t}$. It receives gross interest income on bond holdings, dividend income on mutual fund share holdings and the value of selling its initial share position, and labor income. The household allocates these resources between purchases of bonds and shares to be carried into next period and consumption. Thus, the period budget constraint (in units of consumption) is

$$
\begin{aligned}
& B_{t+1}+Q_{t} B_{*, t+1}+\frac{\eta}{2}\left(B_{t+1}\right)^{2}+\frac{\eta}{2} Q_{t}\left(B_{*, t+1}\right)^{2} \tilde{v}_{t} N_{H, t} x_{t+1}+C_{t}+\bar{C}_{t}= \\
& \left(1+r_{t}\right) B_{t}+\left(1+r_{t}^{*}\right) B_{*, t}+\left(\tilde{d}_{t}+\tilde{v}_{t}\right) N_{D, t} x_{t}+T_{t}^{f}+w_{t} L,
\end{aligned}
$$

where $r_{t}$ is the consumption-based interest rate on holdings of bonds between $t-1$ and $t$ (known with certainty as of $t-1)$ and $(\eta / 2)\left(B_{t+1}\right)^{2}\left((\eta / 2)\left(B_{*, t+1}\right)^{2}\right)$ is the cost of adjusting home (foreign) bonds. The assumption of fees that are quadratic functions of the stock of bonds is sufficient to uniquely pin down the steady-state and deliver stationary model dynamics in response to temporary shocks (see for more details Ghironi, 2006). $T_{t}^{f}$ is the rebate of fees, taken as given by the household, and equal to $(\eta / 2)\left[\left(B_{t+1}\right)^{2}+Q_{t}\left(B_{*, t+1}\right)^{2}\right]$ in equilibrium.

A similar constraint holds for Canada:

$$
\begin{aligned}
& \frac{B_{t+1}^{*}}{Q_{t}}+B_{*, t+1}^{*}+\frac{\eta}{2} \frac{\left(B_{t+1}^{*}\right)^{2}}{Q_{t}}+\frac{\eta}{2}\left(B_{*, t+1}^{*}\right)^{2} \tilde{v}_{t}^{*} N_{F, t}^{*} x_{t+1}^{*}+C_{t}^{*}+\bar{C}_{t}^{*}= \\
& \frac{\left(1+r_{t}\right)}{Q_{t}} B_{t}^{*}+\left(1+r_{t}^{*}\right) B_{*, t}^{*}+\left(\tilde{d}_{t}^{*}+\tilde{v}_{t}^{*}\right) N_{D, t}^{*} x_{t}^{*}+T_{t}^{f *}+w_{t}^{*} L^{*},
\end{aligned}
$$

where $B_{t+1}^{*}$ denotes holdings of the home bond, $B_{*, t+1}^{*}$ denotes holdings of the foreign bond, and $T_{t}^{f *}=(\eta / 2)\left[\left(B_{t+1}^{*}\right)^{2} / Q_{t}+\left(B_{*, t+1}^{*}\right)^{2}\right]$ in equilibrium.

The home and foreign households maximize their expected intertemporal utility subject to (A6) and (A7), respectively.

The Euler equations for share holdings at home are

$$
\tilde{v}_{t}=\beta(1-\delta) E_{t}\left[\left(\frac{C_{t+1}}{C_{t}}\right)^{-\gamma}\left(\tilde{v}_{t+1}+\tilde{d}_{t+1}\right)\right] .
$$


The Euler equations for bond holdings at home are

$$
\begin{aligned}
\left(C_{t}\right)^{-\gamma}\left(1+\eta B_{t+1}\right) & =\beta\left(1+r_{t+1}\right) E_{t}\left[\left(C_{t+1}\right)^{-\gamma}\right], \\
\left(C_{t}\right)^{-\gamma}\left(1+\eta B_{*, t+1}\right) & =\beta\left(1+r_{t+1}^{*}\right) E_{t}\left[\frac{Q_{t+1}}{Q_{t}}\left(C_{t+1}\right)^{-\gamma}\right] .
\end{aligned}
$$

Similar relationship for the Euler equations for share and bond holdings apply abroad.

As expected, forward iteration of the equation for share holdings and absence of speculative bubbles yield the asset price solution in equation (A5).

\section{A3.6 Aggregate Accounting and Labor Market Clearing}

Aggregating the budget constraint (A6) and (A7) across home (foreign) households and imposing the equilibrium conditions under international bond trading $\left(B_{t+1}+B_{t+1}^{*}=B_{*, t+1}+B_{*, t+1}^{*}=0\right.$ and $\left.x_{t+1}=x_{t}=1\right)$ yields the aggregate accounting equation

$$
B_{t+1}+Q_{t} B_{*, t+1}=\left(1+r_{t}\right) B_{t}+Q_{t}\left(1+r_{t}^{*}\right) B_{*, t}+w_{t} L+N_{D, t} \tilde{d}_{t}-N_{E, t} \tilde{v}_{t}-C_{t}-\bar{C}_{t} .
$$

This condition shows that in equilibrium, the markets for home and foreign bonds clear, and each country's net foreign assets entering period $t+1$ depend on interest income from asset holdings entering period $t$, labor income, net investment income (where $N_{E, t} \tilde{v}_{t}$ is the value of home investment in new firms), and consumption during period $t$. The change in asset holdings between $t$ and $t+1$ is the country's current account. A similar equation holds abroad. Home and foreign current accounts add to zero when expressed in units of the same consumption basket.

To close the model, we have to impose labor market clearing at home and abroad, given for America by:

$$
L=\frac{\theta-1}{w_{t}}\left(N_{D, t} \tilde{d}_{D, t}+N_{X, t} \tilde{d}_{X, t}\right)+\frac{1}{Z_{t}}\left(\theta N_{X, t} f_{X, t}+N_{E, t} f_{E, t}\right),
$$

and similarly abroad. 


\section{A4 Calibration}

\section{A4.1 Parametrization of Productivity Draws}

To solve the model numerically, we assume that productivity $z$ is distributed Pareto with lower bound $z_{\min }$ and shape parameter $k>\theta-1: G(z)=1-$ $\left(z_{\min } / z\right)^{k}$. The assumption of a Pareto distribution for productivity induces a size distribution of firms that is also Pareto, which fits firm-level data quite well. $k$ indexes the dispersion of productivity draws: dispersion decreases as $k$ increases, and the firm productivity levels are increasingly concentrated toward their lower bound $z_{\min }$. Letting $v \equiv\{k /[k-(\theta-1)]\}^{1 /(\theta-1)}$, the average productivities $\tilde{z}_{D}$ and $\tilde{z}_{X, t}$ are given by $\tilde{z}_{D}=v z_{\min }$ and $\tilde{z}_{X, t}=v z_{X, t}$. The share of home-exporting firms is then $N_{X, t} / N_{D, t}=1-G\left(z_{X, t}\right)=\left(v z_{\min } / \tilde{z}_{X, t}\right)^{k}$, and the zero export profit condition (for the cutoff firm), $d_{X, t}\left(z_{X, t}\right)=0$, implies that average export profits must satisfy $\tilde{d}_{X, t}=(\theta-1)\left(v^{\theta-1} / k\right) w_{t} f_{X, t} / Z_{t}$. Analogous results hold for $\tilde{z}_{X, t}^{*}$, $N_{X, t}^{*} / N_{D, t}^{*}$, and $\tilde{d}_{X, t}^{*}$.

\section{A4.2 Parametrization of Preferences and Costs}

Every period represents a quarter and $\beta$ is set equal to 0.99 and $\gamma=2$. $\delta$, the exogenous firm exit shock, is set equal to 0.025, which matches the U.S. empirical level of 10 percent job destruction per year. $\theta$ is set equal to 3.8 following Bernard, Eaton, Jensen, and Kortum (2003). They also report that the standard deviation of $\log$ U.S. plant sales is 1.67. As in the given model this standard deviation is equal to $1 /(k-\theta+1)$, the choice of $\theta=3.8$ implies that $k=3.4$. Relying on Obstfeld and Rogoff (2001) we set the steady-state value of trade costs $\bar{\tau}$ equal to 1.3 .

The steady-state fixed export cost $f_{X}$ is set to 23.5 percent of the per-period, amortized flow value of the entry cost, $[1-\beta(1-\delta)] /[\beta(1-\delta)] f_{E}$, such that the proportion of exporting plants matches the 21 percent reported in Bernard, Eaton, Jensen, and Kortum (2003). We set the scale parameter for the bond adjustment cost to $\eta=0.0025$, which is enough to generate stationarity in response to transitory shocks but small enough to avoid overstating the role of this friction in determining the dynamics of the model.

Entry costs $f_{E}$ are set to 1 without loss of generality, as changing $f_{E}$ while maintaining the ratio $f_{X} / f_{E}$ does not affect any of the impulse responses. For similar reasons, we normalize $z_{\min }$ to 1 . Labor endowments are also normalized to 1 , i.e., $L=1$ and $L^{*}=1$. Aggregate labor productivity in steady-state is normalized to one, i.e., $\bar{Z}=1$ and $\bar{Z}^{*}=1$. In steady-state, the exogenous part of consumption is $10 \%$ of endogenous consumption. 


\section{CESifo Working Paper Series}

for full list see www.cesifo-group.org/wp

(address: Poschingerstr. 5, 81679 Munich, Germany, office@cesifo.de)

3144 Philip E. Graves, Benefit-Cost Analysis of Environmental Projects: A Plethora of Systematic Biases, August 2010

3145 Sabrina Di Addario and Daniela Vuri, Entrepreneurship and Market Size. The Case of Young College Graduates in Italy, August 2010

3146 Shoshana Amyra Grossbard and Alfredo Marvăo Pereira, Will Women Save more than Men? A Theoretical Model of Savings and Marriage, August 2010

3147 Jarko Fidrmuc, Time-Varying Exchange Rate Basket in China from 2005 to 2009, August 2010

3148 Ilja Neustadt and Peter Zweifel, Is the Welfare State Sustainable? Experimental Evidence on Citizens' Preferences for Redistribution, August 2010

3149 Marcus Dittrich and Andreas Knabe, Wage and Employment Effects of Non-Binding Minimum Wages, August 2010

3150 Shutao Cao, Enchuan Shao and Pedro Silos, Fixed-Term and Permanent Employment Contracts: Theory and Evidence, August 2010

3151 Ludger Woessmann, Cross-Country Evidence on Teacher Performance Pay, August 2010

3152 Lorenzo C. G. Pozzi, Casper G. de Vries and Jorn Zenhorst, World Equity Premium Based Risk Aversion Estimates, August 2010

3153 Volker Grossmann, Thomas M. Steger and Timo Trimborn, Dynamically Optimal R\&D Subsidization, August 2010

3154 Alexander Haupt, Tim Krieger and Thomas Lange, A Note on Brain Gain and Brain Drain: Permanent Migration and Education Policy, August 2010

3155 António Afonso and Christophe Rault, Long-run Determinants of Sovereign Yields, August 2010

3156 Franziska Tausch, Jan Potters and Arno Riedl, Preferences for Redistribution and Pensions. What can we Learn from Experiments?, August 2010

3157 Martin Kolmar and Andreas Wagener, Inefficient Group Organization as Optimal Adaption to Dominant Environments, August 2010

3158 Kai Carstensen, Klaus Wohlrabe and Christina Ziegler, Predictive Ability of Business Cycle Indicators under Test: A Case Study for the Euro Area Industrial Production, August 2010 
3159 Horst Rottmann and Timo Wollmershäuser, A Micro Data Approach to the Identification of Credit Crunches, August 2010

3160 Philip E. Graves, Appropriate Fiscal Policy over the Business Cycle: Proper Stimulus Policies Can Work, August 2010

3161 Michael Binder and Marcel Bluhm, On the Conditional Effects of IMF Program Participation on Output Growth, August 2010

3162 Michael Binder, Qianying Chen, and Xuan Zhang, On the Effects of Monetary Policy Shocks on Exchange Rates, August 2010

3163 Felix J. Bierbrauer, On the Optimality of Optimal Income Taxation, August 2010

3164 Nikolaus Wolf, Europe's Great Depression - Coordination Failure after the First World War, September 2010

3165 Dan Kovenock and Brian Roberson, Conflicts with Multiple Battlefields, September 2010

3166 Jean-Pierre Ponssard and Catherine Thomas, Capacity Investment under Demand Uncertainty. An Empirical Study of the US Cement Industry, 1994-2006, September 2010

3167 Jørgen Juel Andersen, Jon H. Fiva and Gisle James Natvik, Voting when the Stakes are High, September 2010

3168 Michael Hoel, Is there a Green Paradox?, September 2010

3169 Scott Alan Carson, Nineteenth Century US African-American and White Female Statures: Insight from US Prison Records, September 2010

3170 Gil S. Epstein, Yosef Mealem and Shmuel Nitzan, Political Culture and Discrimination in Contests, September 2010

3171 Sara Fisher Ellison, Jeffrey Greenbaum and Wallace P. Mullin, Diversity, Social Goods Provision, and Performance in the Firm, September 2010

3172 Silvia Dominguez-Martinez, Randolph Sloof and Ferdinand von Siemens, Monitoring your Friends, not your Foes: Strategic Ignorance and the Delegation of Real Authority, September 2010

3173 Marcus Dittrich and Beate Schirwitz, Union Membership and Employment Dynamics: A Note, September 2010

3174 Francesco Daveri, Paolo Manasse and Danila Serra, The Twin Effects of Globalization - Evidence from a Sample of Indian Manufacturing Firms, September 2010

3175 Florian Blöchl, Fabian J. Theis, Fernando Vega-Redondo and Eric O’N. Fisher, Which Sectors of a Modern Economy are most Central?, September 2010 
3176 Dag Morten Dalen, Marilena Locatelli and Steinar Strøm, Longitudinal Analysis of Generic Substitution, September 2010

3177 Armin Falk, Stephan Meier and Christian Zehnder, Did we Overestimate the Role of Social Preferences? The Case of Self-Selected Student Samples, September 2010

3178 Christian Fahrholz and Cezary Wójcik, The Bail-Out! Positive Political Economics of Greek-type Crises in the EMU, September 2010

3179 Klaus Abberger and Wolfgang Nierhaus, The Ifo Business Cycle Clock: Circular Correlation with the Real GDP, September 2010

3180 Walter Krämer and Gerhard Arminger, "True Believers" or Numerical Terrorism at the Nuclear Power Plant, September 2010

3181 Bernard M.S. Van Praag, Dmitri Romanov and Ada Ferrer-i-Carbonell, Happiness and Financial Satisfaction in Israel. Effects of Religiosity, Ethnicity, and War, September 2010

3182 Dimitrios Koumparoulis and Paul De Grauwe, Public Capital, Employment and Productivity: An Empirical Investigation for Greece, September 2010

3183 John Whalley and Tanmaya Shekhar, The Rapidly Deepening India-China Economic Relationship, September 2010

3184 Andreas Schäfer and Thomas Steger, History, Expectations, and Public Policy: Economic Development in Eastern Germany, September 2010

3185 Thomas Eichner and Marco Runkel, Subsidizing Renewable Energy under Capital Mobility, September 2010

3186 Konstantinos Angelopoulos and James Malley, Fear of Model Misspecification and the Robustness Premium, September 2010

3187 Philip E. Graves, A Note on the Design of Experiments Involving Public Goods, September 2010

3188 Glenn Ellison, How does the Market Use Citation Data? The Hirsch Index in Economics, September 2010

3189 Barbara Hanel and Regina T. Riphahn, The Employment of Mothers - Recent Developments and their Determinants in East and West Germany, September 2010

3190 Alexander Haupt and Silke Uebelmesser, Integration, Mobility, and Human Capital Formation, September 2010

3191 Vincenzo Galasso and Paola Profeta, When the State Mirrors the Family: The Design of Pension Systems, September 2010 
3192 Stéphane Zuber and Geir B. Asheim, Justifying Social Discounting: The RankDiscounted Utilitarian Approach, September 2010

3193 Alexander Kemnitz, Educational Federalism and the Quality Effects of Tuition Fees, September 2010

3194 Claudia M. Buch, Sandra Eickmeier and Esteban Prieto, Macroeconomic Factors and Micro-Level Bank Risk, September 2010

3195 May Elsayyad and Kai A. Konrad, Fighting Multiple Tax Havens, September 2010

3196 Laszlo Goerke and Markus Pannenberg, Trade Union Membership and Dismissals, September 2010

3197 Ferdinand Mittermaier and Johannes Rincke, Do Countries Compensate Firms for International Wage Differentials?, September 2010

3198 John Boyd, Gianni De Nicoló and Abu M. Jalal, Bank Competition, Asset Allocations and Risk of Failure: An Empirical Investigation, September 2010

3199 Guido Heineck and Bernd Süssmuth, A Different Look at Lenin's Legacy: Trust, Risk, Fairness and Cooperativeness in the two Germanies, September 2010

3200 Ingvild Almås, Tarjei Havnes and Magne Mogstad, Baby Booming Inequality? Demographic Change and Earnings Inequality in Norway, 1967-2000, October 2010

3201 Thomas Aronsson and Sören Blomquist, The Standard Deviation of Life-Length, Retirement Incentives, and Optimal Pension Design, October 2010

3202 Thorvaldur Gylfason and Eduard Hochreiter, Growing Together: Croatia and Latvia, October 2010

3203 Ken Burdett and Melvyn Coles, Tenure and Experience Effects on Wages: A Theory, October 2010

3204 Wendy Carlin, Good Institutions are not enough: Ongoing Challenges of East German Development, October 2010

3205 Tobias König and Andreas Wagener, Tax Structure and Government Expenditures under Tax Equity Norms, October 2010

3206 Daniel W. Sacks, Betsey Stevenson and Justin Wolfers, Subjective Well-Being, Income, Economic Development and Growth, October 2010

3207 Mario Larch and Wolfgang Lechthaler, Why "Buy American" is a Bad Idea but Politicians still Like it, October 2010 